\title{
Characterization of bacterioplankton communities and quantification of organic carbon pools off the Galapagos Archipelago under contrasting environmental conditions
}

\footnotetext{
Nataly Carolina Guevara Campoverde ${ }^{1,2}$ ， Christiane Hassenrück ${ }^{\text {Corresp., }}{ }^{2}$, Pier Luigi Buttigieg ${ }^{3}$, Astrid Gärdes

${ }^{1}$ Galapagos Science Center, Colegio de Ciencias Biológicas y Ambientales, Universidad San Francisco de Quito, Quito, Ecuador

2 Tropical Marine Microbiology, Department of Biogeochemistry and Geology, Leibniz-Centre for Tropical Marine Reseach, Bremen, Germany

3 HGF-MPG Group for Deep Sea Ecology and Technology, Alfred-Wegener-Institut, Helmholtz-Zentrum für Polar- und Meeresforschung, Bremerhaven, Germany
}

Corresponding Author: Christiane Hassenrück

Email address: christiane.hassenrueck@leibniz-zmt.de

Bacteria play a crucial role in the marine carbon cycle, contributing to the production and degradation of organic carbon. Here, we investigated organic carbon pools, aggregate formation, and bacterioplankton communities in three contrasting oceanographic settings in the Galapagos Archipelago. We studied a submarine $\mathrm{CO}_{2}$ vent at Roca Redonda (RoR), an upwelling site at Bolivar Channel $(\mathrm{BoC})$ subjected to a weak El Niño event at the time of sampling in October 2014, as well as a site without volcanic or upwelling influence at Cowley Islet (Col). We recorded physico-chemical parameters, and quantified particulate and dissolved organic carbon, transparent exopolymeric particles, and the potential of the water to form larger marine aggregates. Free-living and particle-attached bacterial communities were assessed via 16S rRNA gene sequencing. Both RoR and BoC exhibited temperatures elevated by $1-1.5^{\circ} \mathrm{C}$ compared to Col. RoR further experienced reduced $\mathrm{pH}$ between 6.8 and 7.4. We observed pronounced differences in organic carbon pools at each of the three sites, with highest dissolved organic carbon concentrations at BoC and RoR, and highest particulate organic carbon concentrations and aggregate formation at $\mathrm{BoC}$. Bacterioplankton communities at $\mathrm{BoC}$ were dominated by opportunistic copiotrophic taxa, such as Alteromonas and Roseobacter, known to thrive in phytoplankton blooms, as opposed to oligotrophic taxa dominating at Col, such as members of the SAR11 clade. Therefore, we propose that bacterial communities were mainly influenced by the availability of organic carbon at the investigated sites. Our study provides a comprehensive characterization of organic carbon pools and bacterioplankton communities, highlighting the high heterogeneity of various components of the marine carbon cycle around the Galapagos Archipelago. 
1 Characterization of bacterioplankton communities and quantification of organic carbon pools off

2 the Galapagos Archipelago under contrasting environmental conditions

3

4 Nataly Carolina Guevara Campoverde ${ }^{1,2 \pi}$, Christiane Hasenrück ${ }^{19^{*}}$, Pier Luigi Buttigieg ${ }^{3}$, Astrid

5 Gärdes $^{1}$

6

$7 \quad{ }^{1}$ Tropical Marine Microbiology, Department of Biogeochemistry and Geology, Leibniz Centre

8 for Tropical Marine Research, Fahrenheitstraße 6, Bremen, Germany.

9

10

${ }^{2}$ Galapagos Science Center, Colegio de Ciencias Biológicas y Ambientales, Universidad San

11 Francisco de Quito USFQ, Campus Cumbayá, Casilla Postal 17-1200- 841, Quito, Ecuador.

12

${ }^{3}$ HGF-MPG Group for Deep Sea Ecology and Technology, Alfred-Wegener-Institut, Helmholtz-

14 Zentrum für Polar- und Meeresforschung, Am Handelshafen 12, Bremerhaven, Germany.

15

$16 *$ Corresponding author

17 Christiane Hassenrück ${ }^{1}$

18 Email: christiane.hassenrueck@,leibniz-zmt.de

19

20 IEqual contributions 
22 Abstract

23 Bacteria play a crucial role in the marine carbon cycle, contributing to the production and 24 degradation of organic carbon. Here, we investigated organic carbon pools, aggregate formation, 25 and bacterioplankton communities in three contrasting oceanographic settings in the Galapagos Archipelago. We studied a submarine $\mathrm{CO}_{2}$ vent at Roca Redonda (RoR), an upwelling site at Bolivar Channel (BoC) subjected to a weak El Niño event at the time of sampling in October 2014, as well as a site without volcanic or upwelling influence at Cowley Islet (CoI). We recorded physico-chemical parameters, and quantified particulate and dissolved organic carbon, transparent exopolymeric particles, and the potential of the water to form larger marine aggregates. Free-living and particle-attached bacterial communities were assessed via 16S rRNA gene sequencing. Both RoR and $\mathrm{BoC}$ exhibited temperatures elevated by $1-1.5^{\circ} \mathrm{C}$ compared to CoI. RoR further experienced reduced $\mathrm{pH}$ between 6.8 and 7.4. We observed pronounced differences in organic carbon pools at each of the three sites, with highest dissolved organic carbon concentrations at $\mathrm{BoC}$ and $\mathrm{RoR}$, and highest particulate organic carbon concentrations and aggregate formation at $\mathrm{BoC}$. Bacterioplankton communities at $\mathrm{BoC}$ were dominated by opportunistic copiotrophic taxa, such as Alteromonas and Roseobacter, known to thrive in phytoplankton blooms, as opposed to oligotrophic taxa dominating at CoI, such as members of the SAR11 clade. Therefore, we propose that bacterial communities were mainly influenced by the availability of organic carbon at the investigated sites. Our study provides a comprehensive characterization of organic carbon pools and bacterioplankton communities, highlighting the high heterogeneity of various components of the marine carbon cycle around the Galapagos

\section{Archipelago.}




\section{Introduction}

Bacteria play a major role in the marine carbon cycle as primary producers, as well as organic matter degraders. In surface waters, photosynthetic microorganisms convert $\mathrm{CO}_{2}$ into organic carbon, effectively reducing the $\mathrm{pCO}_{2}$ concentration in the upper ocean. While the majority of the organic carbon produced by photosynthesis is respired by heterotrophic organisms and released back into the atmosphere as $\mathrm{CO}_{2}$ (Hutchins et al., 2017), a small portion escapes remineralization and sinks to deeper waters as particulate organic carbon (POC) in the form of marine aggregates (Alldredge \& Silver, 1988; Ducklow et al., 2001; Giering et al., 2014). The formation of these marine aggregates may be enhanced by the presence of transparent exopolymeric particles (TEP; Passow, 2002), which can be formed by cellular exudation from living or lysed cells (Passow et al., 2001; Bhaskar et al., 2005), and which, due to their sticky nature, function as biological glue facilitating aggregation (Jackson, 1995; Engel, 2000). Marine aggregates are heavily colonized by microorganisms and constitute a hotspot of bacterial activity since they contain inorganic and organic nutrients in abundance (Azam and Malfatti, 2007). Particle-attached (PA) bacteria are able to hydrolyze and resuspend the POC of marine aggregates (Azam and Malfatti, 2007; Giering et al. 2014), thereby reducing the vertical flux of organic matter (Grossart \& Ploug 2001). Conversely, free-living (FL) bacteria, which often constitute taxonomically and functionally distinct communities (Rieck et al., 2015), thrive on dissolved organic carbon (DOC) in the ocean (Azam \& Malfatti, 2007). As such, the fate of organic carbon pools in the ocean is tightly coupled to the composition and activity of the FL and PA bacterioplankton community.

The Galapagos Archipelago consists of a group of volcanic islands, located in a complex system of tropical and temperate ocean currents, and intense upwelling zones. Seasonal upwelling occurs on the western side of the Galapagos Archipelago, where the Equatorial Undercurrent (EUC) collides with the iron-rich island platform and is diverted upwards, bringing colder $\left(18^{\circ} \mathrm{C}\right)$ and inorganic nutrient-rich waters to the surface (Houvenaghel, 1978; Palacios, 2002). The increased nutrient supply during the upwelling season is creating a productive area where massive phytoplankton blooms occur and large amount of carbon are converted into organic matter (Jimenez, 1981; Feldman, 1986). Every few years, this seasonal upwelling is suppressed, and surface waters become warmer $\left(26^{\circ} \mathrm{C}\right)$ and depleted of their nutrients. This anomaly, known as El Niño, is thereby preventing the formation of phytoplankton blooms 
78 (Houvenaghel, 1978; Sweet et al. 2007; Liu et al. 2014). The eastern side of the Galapagos Archipelago is governed by the South Equatorial Current (SEC) and does not experience upwelling (Schaeffer et al., 2008). Here, although inorganic nutrient concentrations, specifically nitrate, may reach higher concentrations, primary production is generally limited by the availability of iron, resulting in conditions comparable to the high-nitrate low-chlorophyll (HNLC) areas that characterize most of the eastern and central equatorial Pacific in the absence of an upwelling system (Schaeffer et al., 2008). The Galapagos Archipelago is furthermore among the world's most active volcanic areas today. As a consequence, many islands are characterized by submarine gas seepage through fumaroles consisting mostly of $\mathrm{CO}_{2}$ (Standish et al., 1998), thereby locally reducing seawater $\mathrm{pH}$ and altering the chemical composition of the seawater. Given these contrasting environmental conditions throughout the Galapagos Archipelago, distinct FL and PA bacterioplankton communities as well as organic carbon pools and aggregation processes are expected to occur in different regions of the Galapagos Archipelago.

Previous studies documenting aspects of the marine carbon cycle off the Galapagos Archipelago focused mostly on upwelling and El Niño events, using satellite imagery in combination with in situ measurements to quantify physical water properties, inorganic nutrients and chlorophyll a as proxy for primary production (Palacios, 2004; Sweet et al., 2007; Schaeffer et al., 2008). Data on organic carbon pools around the Galapagos Archipelago are scarce and so far restricted to POC inferred from remote sensing information (Gardner, Mishonov \& Richardson, 2006; Kislik et al., 2017). A direct quantification of DOC and POC, as well as TEP and aggregation processes, is still lacking for this region. Furthermore, apart from isolated observations during global ocean sampling campaigns (Rusch et al., 2007; Yilmaz et al., 2012), no studies have as yet reported on bacterioplankton communities and their potential role in the marine carbon cycle under the varied environmental settings of the Galapagos Archipelago.

The objective of the current study was to investigate various components of the marine carbon cycle by jointly exploring organic carbon pools, aggregate formation, and bacterial community composition under three contrasting environmental conditions around the Galapagos Archipelago. The study sites were selected based on expected temperature and $\mathrm{pH}$ differences: seasonal warming in an area otherwise influenced by upwelling, localized $\mathrm{pH}$ reduction, and an 
108

109

110

111

112

113

114

115

116

117

118

119

120

121

122

123

124

125

126

127

128

129

130

131

132

133

134

135

area outside the upwelling or $\mathrm{pH}$ reduction zones. We aimed (i) to compare the physico-chemical conditions, (ii) to quantify changes in organic carbon pools (POC, DOC, TEP), including the potential for marine aggregate formation, and (iii) to assess differences in the diversity and composition of FL and PA bacterial communities in the water column among these sites. Thereby, we identified bacterial taxa that displayed strong changes in their contribution to bacterioplankton communities at each of the sites, discussing their importance in the marine carbon cycle under the selected environmental conditions.

\section{Materials and methods}

\subsection{Study site}

The sampling was conducted at three sites around the Galapagos Archipelago during a week-long cruise from October 20 to October 27, 2014 (research permit: PNG Permiso de investigacion científica PC-86-14; Fig. 1). The Bolivar Channel (BoC) west of Isabela Island (latitude: $-0.2560667^{\circ}$, longitude: $-91.41733611^{\circ}$ ) is located in an upwelling region, but was exhibiting elevated temperatures caused by the occurrence of a weak El Niño event during the sampling period. Roca Redonda (RoR), located about $25 \mathrm{~km}$ north of Isabela Island (latitude: $0.2817528^{\circ}$, longitude: $-91.61177222^{\circ}$ ), is the nascent peak of a submarine volcano (Standish et al., 1998). $\mathrm{CO}_{2}$ is released through numerous shallow $(10-18 \mathrm{~m})$ vents on the south-eastern side of the peak, locally acidifying the water column. Cowley Islet (CoI), located east of Isabela Island (latitude: $-0.3861444^{\circ}$, longitude: $-90.96356667^{\circ}$ ) showed similar bathymetry to RoR and $\mathrm{BoC}$, while lacking detectable influences from upwelling or geothermal processes.

\subsection{Water sampling}

At each site, spatially separated $(\geq 20 \mathrm{~m}$ ) sub-sites with similar characteristics were selected to replicate the conditions of each site across independent water samples. At CoI and BoC five sub-sites were selected, while at RoR only four sub-sites were sampled due to the limited locations offering similar conditions at accessible depth. At each sub-site, seawater was collected at a depth of approximately $15 \mathrm{~m}$ using a 3 L Niskin bottle. At RoR this sampling depth 
136 corresponded to $50 \mathrm{~cm}$ above the vent. Seawater samples were exported to the Centre for 137 Tropical Marine Research (ZMT), Bremen, Germany, with the approval of the Environmental 138 Ministry of Ecuador (export clearance number 2419373).

139 Temperature, $\mathrm{pH}$, salinity, dissolved oxygen and chlorophyll a concentration of the water 140 column were measured with a Eureka MANTA 2 multi-probe (Eureka Environmental 141 Engineering, Texas, USA), at the same depth the seawater samples were taken. The 142 concentrations of inorganic nutrients (nitrate/nitrite and phosphate) were measured using a continuous flow injection analyzer (FIAstar 5000, Foss Tecator, Denmark).

To investigate different components of the organic carbon pool in the water column, we quantified DOC, TEP, and POC. DOC concentrations were measured by the high-temperature combustion (HTC) technique (Wangersky, 1978; Dafner \& Wangersky, 2002), using a TOCVCPH analyzer (Shimadzu, Mandel, Canada). For the determination of TEP concentrations, 300 $\mathrm{mL}$ water samples were filtered through $0.45 \mu \mathrm{m}$ polycarbonate filters at a constant vacuum of 0.160 bar. TEP was then measured semi-quantitatively using the Xanthan equivalent method

150

151

152

153

154

155

156

157

158

159

160

161

162

163

164

(Engel, 2009; Passow \& Alldredge, 1995). To quantify POC, we filtered 2 L of seawater through a pre-combusted (at $400^{\circ} \mathrm{C}$ ) and pre-weighed $47 \mathrm{~mm}$ glass microfiber filter $(\mathrm{GF} / \mathrm{F})$ in the field using a Millipore ${ }^{\circledR}$ all-glass filtration apparatus. After filtration, we stored the filters in plastic Petri dishes at room temperature $\left(22^{\circ} \mathrm{C}\right)$ until they were dried overnight at $40^{\circ} \mathrm{C}$ in the laboratory and weighed again. We determined the concentration of POC per litre as the difference in filter weight divided by the filtered seawater volume. Data on measured water and carbon pool parameters are available on Pangaea (https://doi.pangaea.de/10.1594/PANGAEA.890858).

\subsection{Rolling tank experiments}

To induce the natural formation of marine aggregates and simulate the continuous sinking of the particles, we performed rolling tank experiments (Shanks and Edmondson, 1989). One cylindrical Plexiglas rolling tank was filled with 1.5 L of the seawater collected at each sub-site. The tanks were rotated for 48 hours at a constant speed of 3 turns per minute. Every 24 hours, we measured aggregate formation by counting aggregates and classifying them into 5 size categories ( $<1 \mathrm{~mm}, 1-3 \mathrm{~mm}, 3-5 \mathrm{~mm}, 5-10 \mathrm{~mm}$ and $>10 \mathrm{~mm}$ ). The rotation of the tanks was briefly 
165 interrupted to count and measure the aggregates non-invasively. Based on the number of

166

167

168

169

170

171

172

173

174

175

176

177

178

179

180

181

182

183

184

185

186

187

188

189

190

191

192

193

194

aggregates in each category, we calculated the total volume of aggregates per tank, assuming spherical shapes (Cárdenas et al., 2015). Data on aggregation potential are available on Pangaea (https://doi.pangaea.de/10.1594/PANGAEA.890858).

\subsection{Bacterial community composition}

The FL and PA fractions of the bacterial community were separated via serial filtration. $1 \mathrm{~L}$ of seawater was first filtered through a $3.0 \mu \mathrm{m}$ polycarbonate filter to collect the PA fraction, followed by filtration through a $0.2 \mu \mathrm{m}$ polycarbonate filter to collect the FL fraction of the bacterial community. Two to four technical replicates were taken at each sub-site. The polycarbonate filters were folded into $1.5 \mathrm{ml}$ Eppendorf tubes with $1 \mathrm{~mL}$ of RNAlater solution (Ambion) and immediately stored at $-20{ }^{\circ} \mathrm{C}$ until DNA extraction. DNA was extracted individually from each technical replicate for both size fractions following the protocol developed by Boström et al. (2004) for low biomass samples. The DNA was quantified using a Bio Photometer Plus spectrophotometer (Eppendorf, Hamburg, Germany). To assess the diversity and composition of the bacterial community, the V3-V4 hypervariable region of the bacterial 16S rRNA gene was sequenced on the Illumina MiSeq PE platform at LGC Genomics $\mathrm{GmbH}$ (Berlin, Germany) using a 2x300bp paired-end approach with universal bacterial primers (Klindworth et al. 2013). Separate libraries were prepared for technical replicates, which were then individually sequenced.

The primer-clipped sequences provided by LGC Genomics were further processed according to (Hassenrück et al., 2016). Sequences were quality trimmed with a sliding window of 4 bases and a minimum average quality score of 15 using trimmomatic version 0.32 (Bolger, Lohse and Usadel 2014). Paired-end reads were merged with PEAR version 0.9.5 (Zhang et al. 2014) using a minimum overlap of 10 base pairs, retaining only merged reads with a minimum and maximum sequence length of 350 and 500 base pairs, respectively. OTU clustering was performed with swarm version 2.0 using the fastidious algorithm with default parameters (Mahé et al. 2014). OTUs consisting of only 1 sequence (singletons) were removed from the data set. As representative sequence per OTU, the seed sequence of each swarm was taxonomically classified with silvangs with default settings (https:/www.arb-silva.de/ngs/; date accessed 
195 02.08.2017) using the SILVA ribosomal RNA gene database version 128 as reference (Quast et 196 al., 2013). Only OTUs that occurred in at least 2 of the technical replicates per sub-site and size 197 fraction were included in the final data set. OTUs of technical replicates were then merged into 198 one community profile per sub-site by taking the sum of the sequence counts per OTU. 199 Furthermore, OTUs with a sequence similarity of less than 93\% to the reference database, OTUs 200 unclassified at phylum level, and OTUs matching chloroplast and mitochondrial sequences were 201 excluded from the analysis. The primer-clipped sequences were deposited in the European 202 Nucleotide Archive (ENA, Toribio et al. 2017) using the data brokerage service of the German 203 Federation for Biological Data (GFBio; Diepenbroek et al. 2014), in compliance with the 204 Minimal Information about any (X) Sequence (MIxS) standard (Yilmaz et al. 2011) and are 205 available with the accession PRJEB27168. The final OTU tables are accessible at Pangaea 206 (https://doi.pangaea.de/10.1594/PANGAEA.890858).

207

208

\subsection{Statistical analysis}

We performed a principal component analysis (PCA) on the measured water and carbon pool parameters after standardizing each variable using z-scoring (Legendre \& Legendre, 1998; Ramette, 2007). Kruskal-Wallis tests were used to detect differences in water and carbon pool parameters between study sites, followed by pairwise comparisons based on Wilcoxon tests with False Discovery Rate (FDR)-corrected p-values (Benjamini and Hochberg, 1995). Aggregation potential was assessed based on the increase in aggregate volume over time during the rolling tank experiments. Differences in aggregate volume between the study sites were tested using general linear mixed models (GLMMs) with sub-site, i.e. rolling tank, as random factor.

Alpha diversity, specifically effective species richness, of the bacterial communities in the FL and PA fraction was assessed with the inverse Simpson index (Chao et al. 2014). No subsampling was required to account for unequal library sizes, since rarefaction curves based on the inverse Simpson index, unlike OTU number, were saturated at observed sequencing depths (SI Fig. 1). Differences in alpha diversity between FL and PA bacterial communities were tested with a paired Wilcoxon test. Patterns in alpha diversity between sampling sites were then analyzed separately within each size fraction using Kruskal-Wallis tests. P-values of pairwise comparisons based on Wilcoxon tests were adjusted using FDR correction (Benjamini and 
225 Hochberg 1995). The relationship between alpha diversity and temperature and $\mathrm{pH}$ was assessed 226 via Spearman rank correlations.

227 Differences in the composition of the bacterial communities (beta diversity) among samples 228 were explored by cluster analysis and tested by analysis of similarity (ANOSIM) using a Bray229 Curtis dissimilarity matrix calculated separately from the OTU data of the FL and PA fraction. 230 Similarity percentages (SIMPER) were used to identify the OTUs contributing most to the 231 dissimilarity between the FL and PA fraction within each water sample. The amount of variation 232 in bacterial community composition explained by sampling site as well as temperature and $\mathrm{pH}$, 233 as parameters of specific interest, was assessed via redundancy analysis (RDA). Separate RDAs 234 were performed for FL and PA communities. Prior to RDA, the data set was reduced by 235 removing OTUs with low sample coverage and rare OTUs, i.e. OTUs occurring in less than 50\% 236 of the samples from at least one site and those contributing less than $1 \%$ to the sequences in at 237 least one sample. There were four main reasons for this reduction step: (i) We were foremost 238 interested in patterns among dominant OTUs. (ii) We wanted to remove statistically 239 uninformative OTUs. OTUs with a low sample coverage are likely outliers and not 240 representative of the conditions in the sampled area, and may therefore bias statistical tests. (iii) 241 To perform further statistical analyses, a centered log ratio (clr)-transformation was applied to 242 the OTU matrix. To enable the log operation a pseudo-count of 0.5 was added to all sequence 243 counts in the OTU matrix (Fernandes et al. 2014). If an OTU matrix contains too many zeros, 244 this addition may bias the original data. Therefore, rare OTUs were excluded to reduce the 245 proportion of zero counts in the OTU matrix. (iv) By reducing the number of OTUs we were 246 further able to increase the sensitivity of statistical approaches requiring multiple testing by 247 applying a less severe p-value correction due to the reduced number of multiple tests. While this 248 removal affected $99 \%$ and $96 \%$ of the OTUs, and $33 \%$ and $25 \%$ of the sequences, in the FL and 249 PA fractions, respectively, we confirmed that it did not alter trends in beta diversity (Mantel test, $250 \mathrm{r}>0.99, \mathrm{p}<0.001)$. Sequence counts were further clr-transformed with the aldex.clr function of 251 the R package ALDEx2, using the median of 128 Monte Carlo Dirichlet instances (Fernandes et 252 al. 2014). ALDEx2 was also used to identify differentially abundant OTUs between sampling 253 sites in the reduced data set of each size fraction at a parametric FDR-adjusted and a non254 parametric unadjusted significance threshold of 0.05. 
255

256

257

258

259

260

261

262

263

264

265

266

267

268

269

270

271

272

273

274

275

276

277

278

279

280

281

282

283

All statistical analyses were conducted in R, using the $\mathrm{R}$ core distribution ( $\mathrm{R}$ Core Team, 2017) with the additional R packages lmerTest (Kuznetsova et al., 2916), vegan (Oksanen et al., 2017), and ALDEx2 (Fernandes et al. 2014). All scripts ( $\mathrm{R}$ and bash) for sequence processing and statistical data analysis are available with the data set on Pangaea (https://doi.pangaea.de/10.1594/PANGAEA.890858).

\section{Results}

\subsection{Water parameters and organic carbon pools}

We observed pronounced differences in measured water parameters and the components of the organic carbon pool in the water column between the sampling sites at CoI, RoR and BoC. Both RoR and $\mathrm{BoC}$ exhibited temperatures elevated by approximately 1 to $1.5^{\circ} \mathrm{C}$ compared to $\mathrm{CoI}$, where values of about $22^{\circ} \mathrm{C}$ were recorded (Table 1). Highest temperatures occurred at BoC with maximum values of $23.8^{\circ} \mathrm{C} . \mathrm{pH}$ ranged from 6.83 at RoR to 8.35 at $\mathrm{BoC}$. Whereas at CoI and $\mathrm{BoC}$ measured $\mathrm{pH}$ values were always above 8 , observed $\mathrm{pH}$ at $\mathrm{RoR}$ did not exceed 7.35 (Table 1). Salinity only varied within a small range among all three sites from 34.38 to 34.72 psu. With the exception of one oxygen measurement of $8.19 \mathrm{mg} \mathrm{L}^{-1}$ at RoR, dissolved oxygen concentrations were highest at $\mathrm{CoI}$ with median values of $6.78 \mathrm{mg} \mathrm{L}^{-1}$, and lowest at $\mathrm{BoC}$ with $6.43 \mathrm{mg} \mathrm{L}^{-1}$. Inorganic nutrients, chlorophyll a, and POC exhibited similar patterns between sampling sites with values 1.5 to 2 times as high at $\mathrm{CoI}$ and $\mathrm{BoC}$ than at RoR (Table 1). For instance, while median POC concentrations of 32.93 and $36.65 \mathrm{mg} \mathrm{L}^{-1}$ were measured at CoI and BoC, respectively, POC concentrations at RoR did not exceed $22.37 \mathrm{mg} \mathrm{L}^{-1}$. Conversely, we observed highest DOC concentrations at RoR and BoC, with median values of $100.54 \mu \mathrm{mol} \mathrm{L}-1$ and $92.14 \mu \mathrm{mol} \mathrm{L}^{-1}$, respectively, as opposed to $80.87 \mu \mathrm{mol} \mathrm{L}-1$ at CoI. The amount of TEP in the water column did not differ significantly between sampling sites (Table 1). Additional to these patterns among sampling sites, most of the measured parameters, except $\mathrm{pH}$, were quite heterogeneous even at the same site, so that the within-site variation was sometimes as large as the between-site variation (Table 1).

The trends in water and carbon pool parameters were summarized in a PCA, which showed well-defined differences among sampling sites (Fig. 2). RoR was separated from CoI and BoC 
284 along principal component (PC) 1, which captured $41.89 \%$ of the total variation in the data set.

285 This separation was driven mostly by $\mathrm{pH}$, nitrate/nitrite, chlorophyll a, and POC. Additionally, 286 CoI was separated from RoR and BoC along PC2, which captured $27.59 \%$ of the total variation 287 in the data set and was mostly determined by temperature, salinity and DOC (Fig. 2).

288

\subsection{Aggregate formation}

290

291

292

293

294

295

296

297

298

299

300

301

302

303

304

305

306

307

308

309

310

311

After filling the rolling tanks, the total aggregate volume per rolling tank at $\mathrm{CoI}$ and $\mathrm{BoC}$ of 0.40 \pm 0.19 and $0.44 \pm 0.13 \mathrm{~cm}^{3}$ (mean \pm standard deviation), respectively, was about one order of magnitude higher than at RoR (Fig. 3). Over the course of the experiment, aggregate volume in the rolling tanks increased at all sites $\left(\mathrm{GLMM}, \mathrm{F}_{2,37}=6.26, \mathrm{p}=0.005\right)$. This potential for aggregate formation differed significantly between sampling sites (GLMM, $\mathrm{F}_{2,37}=25.29$, $\mathrm{p}<$ 0.001). The strongest increase was observed at $\mathrm{BoC}$, where total aggregate volume had more than tripled after $48 \mathrm{~h}\left(1.33 \pm 0.21 \mathrm{~cm}^{3}\right)$ compared to the beginning of the experiment (Fig. 3). At CoI total aggregate volume increased only slightly to $0.64 \pm 0.09 \mathrm{~cm}^{3}$, whereas at RoR even after 48h total aggregate volume $\left(0.08 \pm 0.06 \mathrm{~cm}^{3}\right)$ did not reach initial mean values reported for the other two sites (Fig. 3). Additional to the differences in total aggregate volume between the sampling sites, the size distribution of aggregates was markedly different, with larger aggregates in the range of 5 to $10 \mathrm{~mm}$ dominating the rolling tanks at $\mathrm{CoI}$ and $\mathrm{BoC}$ compared to RoR, where the size of the majority of the aggregates did not exceed $3 \mathrm{~mm}$ (SI Fig. 2). Therefore, even though there were more, but smaller, aggregates in the rolling tanks at RoR, their total volume was not comparable to that of the fewer, but larger, aggregates at $\mathrm{CoI}$ and $\mathrm{BoC}$.

\subsection{Bacterial diversity and community composition}

A total of 798,402 quality-filtered, non-singleton, and taxonomically classified sequences were obtained, which clustered into 14,811 OTUs. After the merging of technical replicates and removal of OTUs not occurring in at least 2 technical replicates per sub-site, 90\% of the sequences were retained while denoising the data set by excluding $60 \%$ of the OTUs, resulting in a final number of 717,420 sequences and 5,970 OTUs. 
Effective species richness (inverse Simpson index) ranged from a minimum of 2.31 in the

313 FL fraction at RoR to a maximum of 65.62 in the PA fraction at CoI. There was no consistent difference between FL and PA effective species richness within the same water sample (paired Wilcoxon test, $\mathrm{V}=47, \mathrm{p}=0.761$ ), although values varied considerably (Table 1 ). Within both the FL and PA fraction, highest median inverse Simpson indices of 33.82 and 48.12, respectively, were recorded at $\mathrm{CoI}$, followed by 21.04 and 17.80 at RoR and 8.46 and 4.85 at BoC, where effective species richness was within a similar range (Table 1).

At class-level, the bacterial communities around the Galapagos Archipelago were dominated by Gammaproteobacteria (48\% of the total number of sequences), Flavobacteriia (17\%), Alphaproteobacteria (16\%), and Cyanobacteria (10\%). Among these dominant bacterial classes, we detected higher proportions of Flavobacteriia, Alphaproteobacteria, and Cyanobacteria at CoI, whereas Gammaproteobacteria were predominantly found at RoR and BoC (Fig. 4). At OTU level, pairwise Bray-Curtis dissimilarities within each water sample between FL and PA bacterial communities ranged from 0.40 to 0.88 , and were comparable to Bray-Curtis dissimilarities among samples within the same size fraction. At CoI these differences between FL and PA bacterial communities were attributed mostly to a lower proportion of OTUs affiliated with the cyanobacterial genus Synechococcus and the OM60 (NOR5) clade of the Gammaproteobacteria, as well as a higher proportion of an OTU affiliated with the verrucomicrobial genus Roseibacillus in the PA fraction. At RoR and BoC, other OTUs contributed most to the differences between size fractions. There, the PA fraction was often dominated by one OTU affiliated with the gammaproteobacterial genus Alteromonas, which constituted 30 to $55 \%$ of the sequences in more than half of the samples at RoR and BoC. community composition among size fractions and sampling sites (Fig. 4), which we further explored using ANOSIM. In the FL fraction, bacterial communities from CoI were very similar to each other with an average within-group dissimilarity of 0.26 , and well-separated from those at RoR and BoC, despite their comparatively low between-group dissimilarity (Table 2). FL communities at RoR and $\mathrm{BoC}$ were more heterogeneous and did not show a strong separation.

340 Within the PA fraction, we observed average within-group Bray-Curtis dissimilarities of 341 approximately 0.50 at all sampling sites. Similar to the FL fraction, strongest differences in 
342 bacterial community composition were detected between $\mathrm{CoI}$ and each of the other two sampling 343 sites. Additionally, the separation of bacterial communities from RoR and BoC was more 344 pronounced in the PA fraction (Table 2).

345 Focusing on common and dominant OTUs, RDA showed that sampling site was able to 346 explain $57 \%$ and $49 \%$ of the variation in bacterial community composition in the FL and PA 347 fraction, respectively (Table 3). The explanatory power of temperature and $\mathrm{pH}$ was not as high as 348 that of sampling site, although the resulting RDA ordinations were very similar (SI Fig. 3). 349 Among the two factors temperature and $\mathrm{pH}$, temperature was able to explain a larger proportion 350 of the variation in community composition than $\mathrm{pH}$. For FL communities, the amount of 351 variation explained by $\mathrm{pH}$ was negligible, whereas its contribution to explaining variation in PA 352 communities was more substantial (Table 3). Including additional water and carbon pool 353 parameters did not increase the model fit according to the Akaike Information Criterion (data not 354 shown).

355 To further identify, which OTUs were responsible for the patterns in community 356 composition, the differences in the proportion of individual OTUs between sampling sites were tested with ALDEx2. In total, 36 and 30 OTUs were detected as differentially abundant between sampling sites within the FL and PA fraction, respectively (Fig. 5). Of those OTUs, 17 showed similar trends in both size fractions. The majority of differentially abundant OTUs in both size fractions was affiliated with Gammaproteobacteria, Flavobacteriia, Alphaproteobacteria, and Verrucomicrobiae, although within each size fraction often different OTUs of those classes exhibited trends between sampling sites. In the FL fraction, differentially abundant OTUs were further found among the Cyanobacteria and Acidimicrobiia, and in the PA fraction among the Cytophaga. In the cases where more than one OTU per class was detected as differentially abundant, those OTUs often exhibited divergent patterns between sampling sites (Fig. 5).

Among the Gammaproteobacteria, OTUs affiliated with the genera Alteromonas, Pseudoalteromonas and Oleibacter were enriched in both size fractions at RoR and BoC, whereas OTUs affiliated with Balneatrix and the OM60 (NOR5) clade were depleted at these sites compared to CoI. Within the PA fraction, one OTU of the genus Thiothrix was further only enriched at RoR. OTUs of the flavobacterial genera Flavicella, Formosa, and the NS4 marine group were characteristic for $\mathrm{CoI}$ in both size fractions. OTUs of the genus Polaribacter showed 
372 divergent trends among sampling sites with different OTUs enriched at either CoI or BoC. Other

373 OTUs of the Flavobacteriia that were strongly enriched at BoC were affiliated with Nonlabens, 374 Mesoflavibacter, and Dokdonia, although differences in the latter were only detected in the FL

375 fraction. Among the Alphaproteobacteria, more OTUs exhibited differences in their sequence 376 proportions between sampling sites in the FL than in the PA fraction. Especially OTUs of the 377 Rhodobacterales, i.e. Candidatus Pelagibacter and another representative of the Surface 1 clade 378 of SAR11, as well as Sulfitobacter and other Rhodobacteraceae, tended to be higher enriched at 379 CoI than at RoR and $\mathrm{BoC}$, although for some OTUs this trend was restricted to the FL fraction. 380 In the case of Sulfitobacter, divergent trends were observed with different OTUs enriched at 381 either $\mathrm{CoI}$ or BoC. OTUs predominantly found at $\mathrm{RoR}$ and $\mathrm{BoC}$ were affiliated with the genus 382 Shimia and Ruegeria, likewise members of the Rhodobacteraceae, although for the latter this 383 pattern was only detected in the PA fraction. Among the Verrucomicrobiae, OTUs of the genus 384 Roseibacillus were depleted at $\mathrm{BoC}$ in both site fractions. OTUs affiliated with Cyanobacteria 385 only differed among sampling sites in the FL fraction, with a decreasing trend of two OTUs of 386 387 388 389 390 391 4. Discussion

\subsection{Physico-chemical characteristics}

We characterized the physico-chemical properties of the water column at each of the three sites at BoC, RoR and CoI. As expected, the three sites exhibited different temperature and $\mathrm{pH}$ conditions. Additionally, we observed marked differences in inorganic nutrients and chlorophyll a concentrations. At $\mathrm{CoI}$ to the east of Isabela Island, temperature and $\mathrm{pH}$ were comparable to previous observations at this site, and can be considered representative for the eastern region of the Galapagos Archipelago during that time of the year (Sweet et al., 2007; Liu et al., 2014). Chlorophyll a concentrations were comparatively low considering the amount of nitrate/nitrite in the water column, resembling HNLC conditions common to the eastern and central equatorial Pacific (Schaeffer et al., 2008). 
402

403

404

405

406

407

408

409

410

411

412

413

414

415

416

417

418

419

420

421

422

423

424

425

426

427

428

429

430

431

$\mathrm{BoC}$ to the west of Isabela Island and $\mathrm{CoI}$ to the east, are influenced by different prevailing ocean currents (Schaeffer et al., 2008; Liu et al., 2014). During upwelling, which constitutes regular conditions at $\mathrm{BoC}$, temperatures drop to about $18^{\circ} \mathrm{C}$, and inorganic nutrient and chlorophyll a concentrations are expected to be considerably higher than any observed in this study (Liu et al., 2014). However, the El Niño event during the sampling period was not as strong as previous events, where temperatures of approximately $26^{\circ} \mathrm{C}$ were reached (Chavez et al., 1999; Palacios, 2004). This suggests that although the upwelling of the EUC was severely reduced, it was not completely inhibited at the time of sampling, thereby limiting but not eliminating the physical resupply of nutrients to surface waters. Probably as a consequence of the weak El Niño, apart from temperature, most of the other observed water parameters were comparable to CoI, and did not resemble the extremes recorded during strong El Niño or La Niña events (Chavez et al., 1999; Palacios, 2004; Liu et al., 2014).

At the submarine volcano at RoR, $\mathrm{pH}$ values were markedly lower than what is considered ambient surface ocean $\mathrm{pH}$ around the Galapagos Archipelago, or indeed most other oceanic regions today (IPCC, 2013), and water temperatures were comparable to BoC. The current system that is influencing BoC, also supplies the north of Isabela Island with nutrient-rich waters under upwelling conditions (Palacios, 2002). However, the weak El Niño event at the time of sampling seemed to strongly diminish this influence, thereby resulting in a stronger influence of the SEC with reduced inorganic nutrients and chlorophyll a concentrations, as well as elevated temperatures at RoR (Schaeffer et al., 2008; Liu et al. 2014).

\subsection{Organic carbon pools under differing environmental regimes}

The amount of organic carbon, partitioned into particulate and dissolved organic carbon that we measured in the surface water off the Galapagos Archipelago was within the range of previous estimates for the equatorial Pacific Ocean (Ogawa \& Tanoue, 2003; Gardner, Mishonov \& Richardson, 2006). Additional to DOC and POC concentration, we evaluated TEP content and aggregation potential to gain a better understanding of the processes that govern particle formation and carbon export. Our results suggest marked differences in the physical and biological processes that influence organic carbon pools at the three sampling sites at the time of sampling, despite a pronounced local variability. 
At $\mathrm{CoI}$ and $\mathrm{BoC}$, congruently elevated inorganic nutrient, chlorophyll a and POC 433 concentrations may indicate increased phytoplankton abundance, with primary production

434

435

436

437

438

439

440

441

442

443

444

445

446

447

448

449

450

451

452

453

454

455

456

457

458

459

460

461

462

contributing to the generation of POC (Ducklow et al., 2001). However, despite these similarities, DOC concentrations and aggregation potential were both considerably higher at BoC. We observed a positive correlation between DOC concentrations and temperature, suggesting that DOC accumulation may be stimulated by the elevated temperature at BoC, a relationship, which has been previously experimentally documented, although for larger temperature differences than those observed here (Wohlers et al., 2009; Kim et al., 2011; Biermann, Engel \& Riebesell, 2014). It has also been shown that increased temperatures promote aggregation formation in phytoplankton blooms due to an increased release of TEP, which is then quickly converted to aggregates (Claquin et al., 2008; Piontek et al., 2009; Biermann, Engel \& Riebesell, 2014), and which may explain the high aggregation potential at BoC. Despite the elevated temperatures, the observed patterns in organic carbon pools and aggregate formation at $\mathrm{BoC}$ therefore further corroborate the occurrence of a weak El Niño event at the time of sampling, where some of the upwelling characteristics were still retained and lead to the formation of a phytoplankton bloom.

DOC concentrations at RoR were similarly elevated as at $\mathrm{BoC}$, presumably likewise related to increased temperatures (Wohlers et al., 2009; Kim et al., 2011; Biermann, Engel \& Riebesell, 2014) rather than reduced $\mathrm{pH}$ (Zark, Riebesell \& Dittmar, 2015). Interestingly, the aggregation potential at RoR was severely diminished compared to the other two sites despite comparable TEP concentrations. Aggregate formation from TEP can be influenced by a decrease in $\mathrm{pH}$, which reduces the stickiness of TEP and thereby its potential to form aggregates (Mari, 2008; Cárdenas et al., 2015). The increased $\mathrm{CO}_{2}$ concentrations in the water column at RoR therefore may have directly impacted aggregate formation. Theoretically, the increased availability of $\mathrm{CO}_{2}$ at RoR can also fuel planktonic primary production (Riebesell et al., 2007). However, chlorophyll a concentrations recorded at RoR suggest otherwise, indicating that other factors may be limiting phytoplankton growth at this site. Indeed, we detected only low amounts of nitrate and phosphate in the water column. Additionally, unobserved parameters, such as iron, may further limit primary production (Palacios, 2002; Tyrrell et al., 2005). These circumstances highlight the fact that the strength of $\mathrm{CO}_{2}$ effects is strongly dependent on the environmental setting (Fu et al., 2008; Sala et al., 2016). 
There are several other factors, which may contribute to explaining the observed patterns in

464

465

466

467

468

469

470

471

472

473

474

475

476

477

478

479

480

481

482

483

484

485

486

487

488

489

490

491

492 organic carbon pools, and which were not investigated here. For instance, the source and composition of the DOC in the water column may affect its fate in the marine carbon cycle (Thornton, 2014). Apart from the recalcitrant DOC pool in the water column, processes such as cell lysis, leakage, and exudation by planktonic and benthic organisms replenish the pool of labile DOC (Haas \& Wild, 2010; Moran et al., 2016). For instance, it is likely that at the time of sampling distinct phytoplankton communities occurred at each of the sampling sites, with a more diverse community at $\mathrm{CoI}$ than at the other two sites (SI Fig. 4), which could have influenced the concentration and composition of the organic carbon pool (Thornton, 2014). Furthermore, the composition of the benthic community most likely differed among the sampling sites, which fall into separate biogeographic regions with distinct benthic communities (Edgar et al., 2004), presumably resulting in differences in the amount and composition of the DOC being released into the water column (Haas \& Wild, 2010; Haas et al., 2011; Cárdenas et al., 2015).

\subsection{Bacterioplankton communities under contrasting environmental conditions}

Bacterial communities in the water column, either free-living or attached to particles, play an important role in the marine carbon cycle, and are strongly interconnected with organic carbon dynamics (Azam \& Malfatti, 2007). This study is the first to describe the diversity and composition of bacterial communities in the waters around the Galapagos Archipelago, apart from isolated observations during the Global Ocean Sampling (GOS) Expedition (Rusch et al., 2007; Yilmaz et al., 2012). In general and at a coarse taxonomic resolution, the composition of the bacterial community described in this study is similar to previous observations from tropical ocean surface waters, including those from the vicinity of the Galapagos Archipelago (Rusch et al., 2007; Zinger et al., 2011; Yilmaz et al., 2012; Sunagawa et al., 2015; Suzuki et al., 2017). However, at a higher taxonomic as well as spatial resolution, we observed pronounced differences in bacterial community composition between size fractions as well as sampling sites. A sizeable proportion of up to $80 \%$ of the sequences per sample were affiliated with taxa that differed in their relative contribution to community composition between the sampling sites, suggesting a major restructuring of bacterial communities with potential implications for bacterial processes involved in carbon cycling in the water column. 
Of the observed environmental parameters, temperature was the main determinant of 494 bacterial community composition in both the FL and PA fractions, whereas pH only played a

495

496

497

498

499

500

501

502

503

504

505

506

507

508

509

510

511

512

513

514

515

516

517

518

519

520

521

522

523 minor role for PA communities. Interestingly, given the correlation of temperature and DOC concentrations in our study, the variation in bacterial community composition explained by temperature, could also be related to changes in DOC concentrations (Borcard, Legendre \& Drapeau, 1992; Ramette, 2007). Changes in bacterial community composition related to temperature and DOC concentrations, respectively, and to a lesser degree $\mathrm{pH}$, further corresponded well with the observed pattern between sampling sites, with communities from RoR and BoC, i.e. the two sites with elevated temperature and DOC concentrations, being more similar to each other than to communities from CoI. In general, these dissimilarities were attributed to a decreased proportion of what could be considered typical oligotrophic bacterioplankton taxa at RoR and BoC, which were strongly dominated by opportunistic copiotrophic bacteria (SI table 1). These changes in community composition therefore also affected community evenness, evident in the strongly diminished effective species richness at $\mathrm{RoR}$ and $\mathrm{BoC}$. In the remainder of this section we will explore the patterns in bacterioplankton composition in more detail.

The only differentially abundant OTU that was enriched only at RoR was affiliated with the gammaproteobacterial genus Thiothrix and occurred almost exclusively in the PA fraction. Thiothrix is a filamentous bacterium capable of sulfur oxidation and usually associated with sulfidic hydrothermal vents, where it exhibits an attached lifestyle (Tarasov et al., 2005; Gugliandolo, Italiano \& Maugeri, 2006; Bailey et al., 2011; Giovannelli et al., 2013; ZapataHernández et al., 2014). Its occurrence at RoR may indicate the presence of sulfide in the area of the hydrothermal gas venting at RoR. Although there were no obvious indications that sulfide was present at the sampling site, i.e. we did not observe a sulfidic smell or white bacterial mats, it is still possible that the community on the particles originated from sulfidic vents that exist in the vicinity of RoR and host mats of bacterial sulfur oxidizers, or that low concentrations of sulfide persisted (Gallardo \& Espinoza, 2007). In the first case, the presence of an OTU may also not necessarily implicate metabolic activity (Lanzen et al., 2011). Furthermore, we did not detect any OTUs enriched exclusively at RoR in the FL fraction. Presumably, the exposure to the acidified water at RoR was insufficient to trigger changes in the composition of the FL bacterial community (Weinbauer et al., 2010). 
524 Synechococcus and Prochlorococcus are two cyanobacterial genera, which are known to 525 comprise the majority of bacterioplankton primary producers in the oligotrophic eastern 526 equatorial Pacific, especially in HNLC areas (Partensky, Blanchot \& Vaulot, 1999; Zubkov et 527 al., 2003; Alvain et al., 2008; Brown et al., 2014). Here, they were predominantly found in the 528 FL fraction at CoI, where they may contribute considerably to TEP production (Iuculano et al., 529 2017). At BoC, and to some degree at RoR, they made up a smaller, although in the case of 530 Synechococcus still substantial, part of the FL bacterioplankton community. Assuming that a 531 diminished phytoplankton bloom developed at BoC under the weak El Niño conditions, 532 eukaryotic phytoplankton, such as representatives of the genera Thalassiosira, Chaetoceros, 533 Emiliania, which have been previously documented in the Galapagos upwelling system 534 (Jimenez, 1981), and which were presumably present at the sampling sites at the time of 535 sampling (SI Fig. 4), may have dominated primary production instead of taxa better adapted to 536 non-bloom conditions (Zubkov et al., 2003; Brown et al., 2014).

537 The remainder of differentially abundant OTUs were affiliated with heterotrophic bacteria 538 involved in the degradation of organic matter. We observed a replacement of organic matter 539 degrading bacterial taxa that may be indicative of functional redundancy, i.e. changing 540 community composition while function is retained (Allison \& Martiny, 2008), but also of distinct 541 bacterial communities adapted to the degradation of different kinds of organic matter, i.e. 542 performing different functions depending on the concentration and composition of the available 543 organic matter (Giovannoni, 2005; Mou et al., 2008; Giebel et al., 2011; Moran et al., 2016). The 544 latter is supported by the differential abundance of mostly oligotrophic taxa at CoI and 545 copiotrophic taxa at RoR and BoC. Among the OTUs predominantly found at CoI, especially 546 members of the SAR11 clade are known to constitute the majority of heterotrophic 547 bacterioplankton in oligotrophic environments, where they are adapted to the degradation of 548 organic matter at low concentrations and predominantly of labile or semi-labile character 549 (Giovannoni, 2005; Moran et al., 2016; Bunse \& Pinhassi, 2017). During periods of high organic 550 matter availability, such as phytoplankton blooms, these oligotrophic taxa are generally 551 outcompeted by copiotrophic organisms.

552 Bacterial communities at RoR and BoC were dominated by OTUs affiliated with 553 representatives of the alphaproteobacterial Roseobacter clade (e.g. Shimia, Ruegeria), several 
554 flavobacterial groups, as well as Alteromonas, and Pseudoalteromonas (Gammaproteobacteria).

555 In general, taxa enriched at RoR and $\mathrm{BoC}$ have been previously associated with phytoplankton 556 blooms in several oceanic regions, where they contribute to the degradation of mostly labile 557 organic matter during the decline of the bloom (Buchan et al., 2014; Teeling et al., 2016). Their 558 opportunistic copiotrophic lifestyle is well-suited to exploit short-term organic matter pulses in 559 an otherwise nutrient-poor environment (López-Pérez et al., 2012). Alteromonas was foremost 560 enriched in PA fraction. Its genetic repertoire encodes for a wide variety of organic matter 561 degrading enzymes, making them highly adapted to utilize the rich availability of substrates on 562 marine aggregates (López-Pérez et al., 2012).

563 The high proportion of Alteromonas in the PA fraction also largely contributed to the 564 dissimilarity between size fractions at $\mathrm{RoR}$ and $\mathrm{BoC}$, whereas at $\mathrm{CoI}$ the prevalence of 565 Synechococcus in the FL fraction was most responsible. Therefore, although FL and PA bacterial 566 communities were consistently different from each other (Rieck et al., 2015; Suzuki et al., 2017), 567 the taxa driving this separation were dependent on the environmental setting. The differences 568 between FL and PA communities were further determined by changes in OTU proportions rather 569 than by a replacement of dominant OTUs. This observation is consistent with Bižić-Ionescu et al. 570 (2015) and Mestre et al. (2017), who detected a considerable proportion of shared taxa between 571 different size fractions, which however differed drastically in their contribution to the 572 community composition of the respective size fractions. Barring technical biases, this situation 573 may indicate that many bacteria are able to switch between FL and PA lifestyles (Grossart, 2010; 574 Bižić-Ionescu et al., 2015; Mestre et al., 2017).

575 Interestingly, in several instances we observed divergent trends in OTU proportions between 576 the sampling sites within the same taxonomic group, specifically Polaribacter (Flavobacteriia), 577 Sulfitobacter and other Rhodobacteraceae (Alphaproteobacteria). These OTUs presumably 578 represent different ecotypes of closely related strains that are adapted to contrasting 579 environmental conditions. Such a phenomenon has been previously reported for the 580 aforementioned taxa, where both oligotrophic and copiotrophic strains with opposing genetic 581 potential were discovered within the same genus (Xing et al., 2015). Sub-genus and sub-species 582 diversity of ecotypes is widespread in microbial ecology, highlighting the importance of high 583 resolution methods, such as the approach employed here (Eren et al., 2014; Mahé et al., 2014). 
584 Overall, the taxonomic profile of the bacterial communities at RoR and BoC closely 585 resembled a community that may be expected during and after phytoplankton blooms occurring 586 under upwelling conditions. We consider this further evidence that the west of Isabela Island was 587 experiencing a weak upwelling event, and associated phytoplankton bloom, during the time of 588 sampling. Indeed, considering the temperature and DOC preferences of the taxonomic groups 589 enriched at RoR and BoC, DOC concentrations, presumably together with DOC composition, 590 may constitute the more likely reason for the observed trends in community composition than 591 any of the other measured environmental parameters. Interestingly, bacterial community 592 composition seemed unrelated to POC concentrations, which differed significantly between RoR 593 and BoC. More extensive data on organic matter quality and composition, which may determine 594 community composition as strongly as quantity, as well as bacterial abundance, which may be 595 more strongly affected by organic matter quantity than community composition (Pinhassi et al., 596 2004; Ortega-Retuerta et al., 2013, Buchan et al., 2014; López-Pérez et al., 2016; Osterholz et 597 al., 2016), will be necessary to further disentangle organic matter and bacterial community 598 dynamics around the Galapagos Archipelago.

\subsection{Conclusion}

601 Our study presents a detailed description of environmental conditions, organic carbon pools, 602 aggregation processes, and bacterioplankton composition, highlighting the high heterogeneity of

603 various components of the marine carbon cycle and bacterial communities around the Galapagos 604 Archipelago, and providing baseline data for future investigations. By employing a combination of different analytical approaches, we were able to characterize the conditions at each of the sampling sites more comprehensively than by any method on its own, and to demonstrate the tight coupling between organic carbon dynamics and bacterioplankton communities. Still, our findings only represent a snapshot in time in a temporally highly variable system. Further research based on repeated observations, including qualitative data on carbon pools, quantitative information on bacterial abundance, as well as estimates of bacterial metabolic activity will be necessary to overcome the limitations and to answer the open questions of the current study, to

612 better understand organic carbon and bacterial community dynamics around the Galapagos 613 Archipelago. 


\section{Acknowledgments}

616 We would like to thank the GSC staff and members, especially to Prof. Dr. Steve Walsh and 617 Dr. Carlos Mena for the logistic support and access to the lab facilities. Also, we are very 618 thankful to Maximilian Hirschfeld, Juan García, Daniela Alarcón, and Eduardo Rosero for their 619 assistance and valuable help during the construction of the onboard lab, the field work and 620 sample collection. We would like to thanks the Galapagos National Park, especially Maryuri 621 Yepez and Galo Quezada, for the logistic support. Also, we would like to thank Anny Cardenas 622 for her advice and suggestions. Special thanks to Maximilian Hirschfeld for your comments and 623 input during all the stages of this project, as well as to Ivaylo Kostadinov and the GFBio team for 624 their support during the data submission.

625

626

\section{References}

627

628

629

630

631

632

633

634

635

636

637

638

639

640

641

642

643

Alldredge AL., Silver MW. 1988. Characteristics, dynamics and significance of marine snow. Progress in Oceanography 20:41-82. DOI: 10.1016/0079-6611(88)90053-5.

Allison SD., Martiny JBH. 2008. Colloquium paper: resistance, resilience, and redundancy in microbial communities. PNAS 105:11512-11519. DOI: 10.1073/pnas.0801925105.

Alvain S., Moulin C., Dandonneau Y., Loisel H. 2008. Seasonal distribution and succession of dominant phytoplankton groups in the global ocean: A satellite view. Global Biogeochemical Cycles 22:1-15. DOI: 10.1029/2007GB003154.

Azam F., Malfatti F. 2007. Microbial structuring of marine ecosystems. Nature Reviews Microbiology 5:782-791. DOI: 10.1038/nrmicro1747.

Bailey J V., Salman V., Rouse GW., Schulz-Vogt HN., Levin LA., Orphan VJ. 2011.

Dimorphism in methane seep-dwelling ecotypes of the largest known bacteria. The ISME Journal 5:1926-1935. DOI: 10.1038/ismej.2011.66.

Benjamini Y., Hochberg Y. 1995. Controlling the False Discovery Rate: A Practical and Powerful Approach to Multiple Testing. Journal of the Royal Statistical Society. Series B (Methodological) 57:289-300. DOI: 10.2307/2346101.

Bhaskar PV., Grossart HP., Bhosle NB., Simon M. 2005. Production of macroaggregates from dissolved exopolymeric substances (EPS) of bacterial and diatom origin. FEMS 
644

645

646

647

648

649

650

651

652

653

654

655

656

657

658

659

660

661

662

663

664

665

666

667

668

669

670

671

672

673

674

Microbiology Ecology 53:255-264.

Biermann A., Engel A., Riebesell U. 2014. Changes in organic matter cycling in a plankton community exposed to warming under different light intensities. Journal of Plankton Research 36:658-671. DOI: 10.1093/plankt/fbu005.

Bižić-Ionescu M., Zeder M., Ionescu D., Orlić S., Fuchs BM., Grossart HP., Amann R. 2015. Comparison of bacterial communities on limnic versus coastal marine particles reveals profound differences in colonization. Environmental Microbiology 17:3500-3514. DOI: $10.1111 / 1462-2920.12466$.

Borcard D., Legendre P., Drapeau P. 1992. Partialling out the Spatial Component of Ecological Variation. Ecology 73:1045-1055.

Brown M V., Ostrowski M., Grzymski JJ., Lauro FM. 2014. A trait based perspective on the biogeography of common and abundant marine bacterioplankton clades. Marine Genomics 15:17-28. DOI: 10.1016/j.margen.2014.03.002.

Buchan A., LeCleir GR., Gulvik CA., González JM. 2014. Master recyclers: features and functions of bacteria associated with phytoplankton blooms. Nature Reviews Microbiology 12:686-698. DOI: 10.1038/nrmicro3326.

Bunse C., Pinhassi J. 2017. Marine Bacterioplankton Seasonal Succession Dynamics. Trends in Microbiology 25:494-505. DOI: 10.1016/j.tim.2016.12.013.

Cárdenas A., Meyer F., Schwieder H., Wild C., Gärdes A. 2015. The formation of aggregates in coral reef waters under elevated concentrations of dissolved inorganic and organic carbon: A mesocosm approach. Marine Chemistry 175:47-55. DOI:

10.1016/j.marchem.2015.04.002.

Chavez F., Strutton P., Friederich G., Feely R., Feldman G., Foley D., McPhaden M. 1999. Biological and Chemical Response of the Equatorial Pacific Ocean to the $1997-98$ El Niño. Science 286:2126-2131. DOI: 10.1126/science.286.5447.2126.

Claquin P., Probert I., Lefebvre S., Veron B. 2008. Effects of temperature on photosynthetic parameters and TEP production in eight species of marine microalgae. Aquatic Microbial Ecology 51:1-11. DOI: 10.3354/ame01187.

Dafner EV., Wangersky PJ. 2002. A brief overview of modern directions in marine DOC studies Part II - recent progress in marine DOC studies. Journal of Environmental Monitoring 4:55-69. 
675 Diepenbroek M., Glöckner F., Grobe P., Güntsch A., Huber R., König-Ries B., Kostadinov I.,

676 Nieschulze J., Seeger B., Tolksdorf R., Triebel D. 2014. Towards an Integrated Biodiversity

677 and Ecological Research Data Management and Archiving Platform: The German

678 Federation for the Curation of Biological Data (GFBio). In: Plödereder E, Grunske L,

679 Schneider E \& Ull D eds. Informatik 2014 - Big Data Komplexität meistern. Bonn: Köllen

680 Verlag, GI-Edition: Lecture Notes in Informatics (LNI) - Proceedings 232: 1711-1724.

681 Ducklow HHW., Steinberg DDK., Buessler K., Buesseler KO. 2001. Upper ocean carbon export 682 and the biological pump. Oceanography 14:50-58. DOI: 10.5670/oceanog.2001.06.

683 Edgar GJ., Banks S., Farina JM., Calvopina M., Martinez C. 2004. Regional biogeography of 684 shallow reef fish and macro-invertebrate communities in the Galapagos archipelago.

685 Journal of Biogeography 31:1107-1124. DOI: 10.1111/j.1365-2699.2004.01055.x.

686 Engel A. 2009. Determination of Marine Gel Particles. In: Wurl O ed. Practical Guidelines for

687 the Analysis of Seawater. Boca Raton: Taylor \& Francis, 125-142.

688 Eren AM., Morrison HG., Lescault PJ., Reveillaud J., Vineis JH., Sogin ML. 2014. Minimum

689 entropy decomposition : Unsupervised oligotyping for sensitive partitioning of high-

690 throughput marker gene sequences. The ISME Journal 9:968-979. DOI:

$691 \quad$ 10.1038/ismej.2014.195.

692 Fu F., Mulholland MR., Garcia NS., Beck A., Bernhardt PW., Warner ME., Sanudo-Wilhelmy

693 SA., Hutchins DA. 2008. Interactions between changing pCO2, N2 fixation, and Fe

694 limitation in the marine unicellular cyanobacterium Crocosphaera. Limnology and

695 Oceanography 53:2472-2484. DOI: 10.4319/1o.2008.53.6.2472.

696 Gallardo VA., Espinoza C. 2007. New communities of large filamentous sulfur bacteria in the 697 eastern South Pacific. International Microbiology 10:97-102. DOI: 10.2436/20.1501.01.14. 698 Gardner WD., Mishonov A V., Richardson MJ. 2006. Global POC concentrations from in-situ 699 and satellite data. Deep-Sea Research Part II 53:718-740. DOI:

$700 \quad$ 10.1016/j.dsr2.2006.01.029.

701 Giebel H-A., Kalhoefer D., Lemke A., Thole S., Gahl-Janssen R., Simon M., Brinkhoff T. 2011. 702 Distribution of Roseobacter RCA and SAR11 lineages in the North Sea and characteristics 703 of an abundant RCA isolate. The ISME Journal 5:8-19. DOI: 10.1038/ismej.2010.87.

704 Giering SLC., Sanders R., Lampitt RS., Anderson TR., Tamburini C., Boutrif M., Zubkov M V., 705 Marsay CM., Henson SA., Saw K., Cook K., Mayor DJ. 2014. Reconciliation of the carbon 
706

707

708

709

710

711

712

713

714

715

716

717

718

719

720

721

722

723

724

725

726

727

728

729

730

731

732

733

734

735

736

budget in the ocean's twilight zone. Nature 507:480-483. DOI: 10.1038/nature13123.

Giovannelli D., d’Errico G., Manini E., Yakimov M., Vetriani C. 2013. Diversity and phylogenetic analyses of bacteria from a shallow-water hydrothermal vent in Milos island (Greece). Frontiers in Microbiology 4:1-13. DOI: 10.3389/fmicb.2013.00184.

Giovannoni SJ. 2005. Genome Streamlining in a Cosmopolitan Oceanic Bacterium. Science 309:1242-1245. DOI: 10.1126/science.1114057.

Grossart HP. 2010. Ecological consequences of bacterioplankton lifestyles: Changes in concepts are needed. Environmental Microbiology Reports 2:706-714. DOI: 10.1111/j.17582229.2010.00179.x.

Grossart HP., Ploug H. 2001. Microbial degradation of organic carbon and nitrogen on diatom aggregates. Limnology and Oceanography 46:267-277. DOI: 10.4319/lo.2001.46.2.0267.

Gugliandolo C., Italiano F., Maugeri T. 2006. The submarine hydrothermal system of Panarea (Southern Italy): biogeochemical processes at the thermal fluids - sea bottom interface. Annals of Geophysics 49:783-792.

Haas AF., Nelson CE., Kelly LW., Carlson CA., Rohwer F., Leichter JJ., Wyatt A., Smith JE. 2011. Effects of coral reef benthic primary producers on dissolved organic carbon and microbial activity. PLOS ONE 6:e27973. DOI: 10.1371/journal.pone.0027973.

Haas AF., Wild C. 2010. Composition analysis of organic matter released by cosmopolitan coral reef-associated green algae. Aquatic Biology 10:131-138. DOI: 10.3354/ab00271.

Hassenrück C., Fink A., Lichtschlag A., Tegetmeyer HE., de Beer D., Ramette A. 2016. Quantification of the effects of ocean acidification on sediment microbial communities in the environment: the importance of ecosystem approaches. FEMS Microbiology Ecology 92:1-12. DOI: 10.1093/femsec/fiw027.

Houvenaghel GT. 1978. Oceanographic conditions in the Galapagos Archipelago and their relationships with life on the islands. In: Boje R, Tomczak M eds. Upwelling Ecosystems. Springer, Berlin, Heidelberg. DOI: 10.1007/978-3-642-66985-9_15.

Hutchins DA., Fu F., Sedwick PN., Stehr G. 2017. Microorganisms and ocean global change. Nature Microbiology 2:17058. DOI: 10.1038/nmicrobiol.2017.58.

IPCC. 2013. Summary for Policymakers. In: Stocker TF, Qin D, Plattner G-K, Tignor K, Allen SK, Boschung J, Nauels A, Xia Y, Bex V, Midgley PM eds. Climate Change 2013: The Physical Science Basis. Contribution of Working Group I to the Fifth Assessment Report of 
737

738

739

740

741

742

743

744

745

746

747

748

749

750

751

752

753

754

755

756

757

758

759

760

761

762

763

764

765

766

767

the Intergovernmental Panel on Climate Change. Cambridge, United Kingdom and New York, NY, USA: Cambridge University Press, 1-30. DOI: 10.1017/CBO9781107415324.

Iuculano F., Mazuecos IP., Reche I., Agustí S. 2017. Prochlorococcus as a possible source for transparent exopolymer particles (TEP). Frontiers in Microbiology 8:1-11. DOI:

10.3389/fmicb.2017.00709.

Jimenez R. 1981. Composition and distribution of phytoplankton in the upwelling system of the Galapagos Islands. Coastal and Estuarine Sciences 1:39-43.

Kim JM., Lee K., Shin K., Yang EJ., Engel A., Karl DM., Kim HC. 2011. Shifts in biogenic carbon flow from particulate to dissolved forms under high carbon dioxide and warm ocean conditions. Geophysical Research Letters 38:1-5. DOI: 10.1029/2011GL047346.

Kislik E., Mantilla G., Torres G., Borbor-Córdova M. 2017. Biological Hotspots in the Galápagos Islands: Exploring Seasonal Trends of Ocean Climate Drivers to Monitor Algal Blooms. International Journal of Bioengineering and Life Sciences 11:784-794.

Lanzen A., Jorgensen SL., Bengtsson MM., Jonassen I., Ovreas L., Urich T. 2011. Exploring the composition and diversity of microbial communities at the Jan Mayen hydrothermal vent field using RNA and DNA. FEMS Microbiology Ecology 77:577-589. DOI: 10.1111/j.1574-6941.2011.01138.x.

Legendre P., Legendre L. 1998. Numerical Ecology. Amsterdam: Elsevier.

Liu Y., Xie L., Morrison JM., Kamykowski D., Sweet W V. 2014. Ocean Circulation and Water Mass Characteristics around the Galápagos Archipelago Simulated by a Multiscale Nested Ocean Circulation Model. International Journal of Oceanography 2014:1-16. DOI: 10.1155/2014/198686.

López-Pérez M., Gonzaga A., Martin-Cuadrado A-B., Onyshchenko O., Ghavidel A., Ghai R., Rodriguez-Valera F. 2012. Genomes of surface isolates of Alteromonas macleodii: the life of a widespread marine opportunistic copiotroph. Scientific Reports 2:696. DOI: 10.1038/srep00696.

López-Pérez M., Kimes NE., Haro-Moreno JM., Rodriguez-Valera F. 2016. Not all particles are equal: The selective enrichment of particle-associated bacteria from the mediterranean sea. Frontiers in Microbiology 7:996. DOI: 10.3389/fmicb.2016.00996.

Mahé F., Rognes TT., Quince C., de Vargas C., Dunthorn M. 2014. Swarm: robust and fast clustering method for amplicon-based studies. PeerJ 2:e593. DOI: 
768

769

770

771

772

773

774

775

776

777

778

779

780

781

782

783

784

785

786

787

788

789

790

791

792

793

794

795

796

797

798

http://dx.doi.org/10.7287/peerj.preprints.386v1.

Mari X. 2008. Does ocean acidification induce an upward flux of marine aggregates?

Biogeosciences Discussions 5:1631-1654. DOI: 10.5194/bgd-5-1631-2008.

Mestre M., Borrull E., Sala M., Gasol JM. 2017. Patterns of bacterial diversity in the marine planktonic particulate matter continuum. ISME Journal 11:999-1010. DOI: 10.1038/ismej.2016.166.

Moran MA., Kujawinski EB., Stubbins A., Fatland R., Aluwihare LI., Buchan A., Crump BC., Dorrestein PC., Dyhrman ST., Hess NJ., Howe B., Longnecker K., Medeiros PM., Niggemann J., Obernosterer I., Repeta DJ., Waldbauer JR. 2016. Deciphering ocean carbon in a changing world. PNAS 113:3143-3151. DOI: 10.1073/pnas.1514645113.

Mou X., Sun S., Edwards R a., Hodson RE., Moran MA. 2008. Bacterial carbon processing by generalist species in the coastal ocean. Nature 451:708-11. DOI: 10.1038/nature06513.

Ogawa H., Tanoue E. 2003. Dissolved Organic Matter in Oceanic Waters. Journal of Oceanography 59:129-147.

Ortega-Retuerta E., Joux F., Jeffrey WH., Ghiglione JF. 2013. Spatial variability of particleattached and free-living bacterial diversity in surface waters from the Mackenzie River to the Beaufort Sea (Canadian Arctic). Biogeosciences 10:2747-2759. DOI: 10.5194/bg-102747-2013.

Osterholz H., Singer G., Wemheuer B., Daniel R., Simon M., Niggemann J., Dittmar T. 2016. Deciphering associations between dissolved organic molecules and bacterial communities in a pelagic marine system. The ISME Journal 10:1717-1730. DOI: 10.1038/ismej.2015.231.

Palacios DM. 2002. Factors influencing the island-mass effect of the Galápagos Archipelago. Geophysical Research Letters 29:1-4. DOI: 10.1029/2002GL016232.

Palacios DM. 2004. Seasonal patterns of sea-surface temperature and ocean color around the Galapagos: Regional and local influences. Deep-Sea Research Part II 51:43-57. DOI: 10.1016/j.dsr2.2003.08.001.

Partensky F., Blanchot J., Vaulot D. 1999. Differential distribution and ecology of Prochlorococcus and Synechococcus in oceanic waters: a review. Bulletin de l'Institut océanographique 19:457-475.

Passow U. 2002. Transparent exopolymer particles (TEP) in aquatic environments. Progress in 
799

800

801

802

803

804

805

806

807

808

809

810

811

812

813

814

815

816

817

818

819

820

821

822

823

824

825

826

827

828

829

Oceanography 55:287-333. DOI: 10.1016/S0079-6611(02)00138-6.

Passow U., Alldredge AL. 1995. Aggregation of a diatom bloom in a mesocosm: The role of transparent exopolymer particles (TEP). Deep-Sea Research Part II 42:99-109. DOI: 10.1016/0967-0645(95)00006-C.

Passow U., Shipe RF., Murray A., Pak DK., Brzezinski MA., Alldredge AL. 2001. The origin of transparent exopolymer particles (TEP) and their role in the sedimentation of particulate matter. Continental Shelf Research 21:327-346. DOI: 10.1016/S0278-4343(00)00101-1.

Pinhassi J., Sala MM., Havskum H., Peters F., Guadayol Ò., Malits A., Marrasé C. 2004. Changes in bacterioplankton composition under different phytoplankton regimens. Applied and Environmental Microbiology 70:6753-6766. DOI: 10.1128/AEM.70.11.67536766.2004 .

Piontek J., Händel N., Langer G., Wohlers J., Riebesell U., Engel a. 2009. Effects of rising temperature on the formation and microbial degradation of marine diatom aggregates. Aquatic Microbial Ecology 54:305-318. DOI: 10.3354/ame01273.

Ramette A. 2007. Multivariate analyses in microbial ecology. FEMS Micriobiology Ecology 62:142-60. DOI: 10.1111/j.1574-6941.2007.00375.x.

Riebesell U., Schulz KG., Bellerby RGJ., Botros M., Fritsche P., Meyerhöfer M., Neill C., Nondal G., Oschlies A., Wohlers J., Zöllner E. 2007. Enhanced biological carbon consumption in a high CO2 ocean. Nature 450:545-548. DOI: 10.1038/nature06267.

Rieck A., Herlemann DPR., Jürgens K., Grossart HP. 2015. Particle-associated differ from freeliving bacteria in surface waters of the baltic sea. Frontiers in Microbiology 6. DOI: 10.3389/fmicb.2015.01297.

Rusch DB., Halpern AL., Sutton G., Heidelberg KB., Williamson S., Yooseph S., Wu D., Eisen JA., Hoffman JM., Remington K., Beeson K., Tran B., Smith H., Baden-Tillson H., Stewart C., Thorpe J., Freeman J., Andrews-Pfannkoch C., Venter JE., Li K., Kravitz S., Heidelberg JF., Utterback T., Rogers YH., Falcon LI., Souza V., Bonilla-Rosso G., Eguiarte LE., Karl DM., Sathyendranath S., Platt T., Bermingham E., Gallardo V., Tamayo-Castillo G., Ferrari MR., Strausberg RL., Nealson K., Friedman R., Frazier M., Venter JC. 2007. The Sorcerer II Global Ocean Sampling expedition: Northwest Atlantic through eastern tropical Pacific. PLoS Biology 5:0398-0431. DOI: 10.1371/journal.pbio.0050077.

Sala MM., Aparicio FL., Boras JA., Borrull E., Cardelus C., Cros L., Gomes A., Lopez-Sanz A., 
830

831

832

833

834

835

836

837

838

839

840

841

842

843

844

845

846

847

848

849

850

851

852

853

854

855

856

857

858

859

860

Malits A., Martinez RA., Mestre M., Movilla J., Sarmento H., Vazquez-Dominguez E., Vaque D., Pinhassi J., Calbet A., Calvo E., Gasol JM., Pelejero C., Marrase C. 2016. Contrasting effects of ocean acidification on the microbial food web under different trophic conditions. ICES Journal of Marine Science 73:670-679.

Schaeffer BA., Morrison JM., Kamykowski D., Feldman GC., Xie L., Liu Y., Sweet W., McCulloch A., Banks S. 2008. Phytoplankton biomass distribution and identification of productive habitats within the Galapagos Marine Reserve by MODIS, a surface acquisition system, and in-situ measurements. Remote Sensing of Environment 112:3044-3054. DOI: 10.1016/j.rse.2008.03.005.

Standish J., Geist D., Harpp K., Kurz MD. 1998. The emergence of a Galapagos shield volcano, Roca Redonda. Contributions to Mineralogy and Petrology 133:136-148. DOI: $10.1007 / \mathrm{s} 004100050443$.

Sunagawa S., Coelho LP., Chaffron S., Kultima JR., Labadie K., Salazar G., Djahanschiri B., Zeller G., Mende DR., Alberti A., Cornejo-castillo FM., Costea PI., Cruaud C., Ovidio F., Engelen S., Ferrera I., Gasol JM., Guidi L., Hildebrand F., Kokoszka F., Lepoivre C. 2015. Structure and function of the global ocean microbiome. Science 348:1-10.

Suzuki S., Kaneko R., Kodama T., Hashihama F., Suwa S., Tanita I., Furuya K., Hamasaki K. 2017. Comparison of community structures between particle-associated and free-living prokaryotes in tropical and subtropical Pacific Ocean surface waters. Journal of Oceanography 73:383-395. DOI: 10.1007/s10872-016-0410-0.

Sweet W V., Morrison JM., Kamykowski D., Schaeffer BA., Banks S., McCulloch A. 2007. Water mass seasonal variability in the Galapagos Archipelago. Deep-Sea Research Part I 54:2023-2035. DOI: 10.1016/j.dsr.2007.09.009.

Tarasov VG., Gebruk A V., Mironov AN., Moskalev LI. 2005. Deep-sea and shallow-water hydrothermal vent communities: Two different phenomena? Chemical Geology 224:5-39. DOI: 10.1016/j.chemgeo.2005.07.021.

Teeling H., Fuchs BM., Bennke CM., Krüger K., Chafee M., Kappelmann L., Reintjes G., Waldmann J., Quast C., Glöckner FO., Lucas J., Wichels A., Gerdts G., Wiltshire KH., Amann RI. 2016. Recurring patterns in bacterioplankton dynamics during coastal spring algae blooms. eLife 5:1-31. DOI: 10.7554/eLife.11888.

Thornton DCO. 2014. Dissolved organic matter (DOM) release by phytoplankton in the 
861

862

863

864

865

866

867

868

869

870

871

872

873

874

875

876

877

878

879

880

881

882

883

884

885

886

887

888

889

890

891

contemporary and future ocean. European Journal of Phycology 49:20-46. DOI: 10.1080/09670262.2013.875596.

Toribio AL., Alako B., Amid C., Cerdeno-Tarraga A., Clarke L., Cleland I., Fairley S., Gibson R., Goodgame N., Hoopen P ten., Jayathilaka S., Kay S., Leinonen R., Liu X., MartinezVillacorta J., Pakseresht N., Rajan J., Reddy K., Rosello M., Silvester N., Smirnov D., Vaughan D., Zalunin V., Cochran G. 2017. The European Nucleotide Archive in 2016. Nucleic Acids Research 46:D32-D36. DOI: 10.1093/nar/gkx1125.

Tyrrell T., Merico A., Waniek JJ., Wong CS., Metzl N., Whitney F. 2005. Effect of seafloor depth on phytoplankton blooms in high-nitrate, low-chlorophyll (HNLC) regions. Journal of Geophysical Research 110:G02007. DOI: 10.1029/2005JG000041.

Wangersky PJ. 1978. Methods of seawater analysis. Marine Chemistry 7:86-87.

Weinbauer MG., Kerros ME., Motegi C., Wilhartitz IC., Rassoulzadegan F., Torreton JP., Mari X. 2010. Bacterial community composition and potential controlling mechanisms along a trophic gradient in a barrier reef system. Aquatic Microbial Ecology 60:15-28. DOI: 10.3354/ame01411.

Wohlers J., Engel A., Zöllner E., Breithaupt P., Jürgens K., Hoppe HG., Sommer U., Riebesell U. 2009. Changes in biogenic carbon flow in response to sea surface warming. PNAS 106:7067-7072.

Xing P., Hahnke RL., Unfried F., Markert S., Huang S., Barbeyron T., Harder J., Becher D., Schweder T., Glöckner FO., Amann RI., Teeling H. 2015. Niches of two polysaccharidedegrading Polaribacter isolates from the North Sea during a spring diatom bloom. The ISME Journal 9:1410-1422. DOI: 10.1038/ismej.2014.225.

Yilmaz P., Iversen MH., Hankeln W., Kottmann R., Quast C., Glöckner FO. 2012. Ecological structuring of bacterial and archaeal taxa in surface ocean waters. FEMS Microbiology Ecology 81:373-385. DOI: 10.1111/j.1574-6941.2012.01357.x.

Yilmaz P., Kottmann R., Field D., Knight R., Cole JR., Amaral-Zettler L., Gilbert JA., KarschMizrachi I., Johnston A., Cochrane G., Vaughan R., Hunter C., Park J., Morrison N., RoccaSerra P., Sterk P., Arumugam M., Bailey M., Baumgartner L., Birren BW., Blaser MJ., Bonazzi V., Booth T., Bork P., Bushman FD., Buttigieg PL., Chain PSG., Charlson E., Costello EK., Huot-Creasy H., Dawyndt P., Desantis T., Fierer N., Fuhrman JA., Gallery RE., Gevers D., Gibbs RA., Gil IS., Gonzalez A., Gordon JI., Guralnick R., Hankeln W., 
892

893

894

895

896

897

898

899

900

901

902

903

904

905

906

907

908

909

910

911

912

913

914

915

916

917

Highlander S., Hugenholtz P., Jansson J., Kau AL., Kelley ST., Kennedy J., Knights D., Koren O., Kuczynski J., Kyrpides N., Larsen R., Lauber CL., Legg T., Ley RE., Lozupone CA., Ludwig W., Lyons D., Maguire E., Methé BA., Meyer F., Muegge B., Nakielny S., Nelson KE., Nemergut D., Neufeld JD., Newbold LK., Oliver AE., Pace NR., Palanisamy G., Peplies J., Petrosino J., Proctor L., Pruesse E., Quast C., Raes J., Ratnasingham S., Ravel J., Relman DA., Assunta-Sansone S., Schloss PD., Schriml L., Sinha R., Smith MI., Sodergren E., Spor A., Stombaugh J., Tiedje JM., Ward D V., Weinstock GM., Wendel D., White O., Whiteley A., Wilke A., Wortman JR., Yatsunenko T., Glöckner FO. 2011. Minimum information about a marker gene sequence (MIMARKS) and minimum information about any $(x)$ sequence (MIxS) specifications. Nature Biotechnology 29:415420. DOI: $10.1038 /$ nbt. 1823.

Zapata-Hernández G., Sellanes J., Mayr C., Muñoz P. 2014. Benthic food web structure in the Comau fjord, Chile $\left(\sim 42^{\circ} \mathrm{S}\right)$ : Preliminary assessment including a site with chemosynthetic activity. Progress in Oceanography 129:149-158. DOI: 10.1016/j.pocean.2014.03.005.

Zark M., Riebesell U., Dittmar T. 2015. Effects of ocean acidification on marine dissolved organic matter are not detectable over the succession of phytoplankton blooms. Science Advances 1:e1500531-e1500531. DOI: 10.1126/sciadv.1500531.

Zinger L., Amaral-Zettler L a., Fuhrman J a., Horner-Devine MC., Huse SM., Welch DBM., Martiny JBH., Sogin M., Boetius A., Ramette A. 2011. Global patterns of bacterial betadiversity in seafloor and seawater ecosystems. PloS one 6:e24570. DOI: 10.1371/journal.pone.0024570.

Zubkov M V., Fuchs BM., Tarran GA., Burkill PH., Amann R. 2003. High Rate of Uptake of Organic Nitrogen Compounds by Prochlorococcus Cyanobacteria as a key to their dominance in Oligortrophic oceanic waters. Applied and Environmental Microbiology 69:1299-1304. DOI: 10.1128/AEM.69.2.1299. 


\section{Figure 1 (on next page)}

Map of the sampling sites at Cowley Islet (Col), Roca Redonda (RoR), and Bolivar Channel (BoC) around the Galapagos Islands 


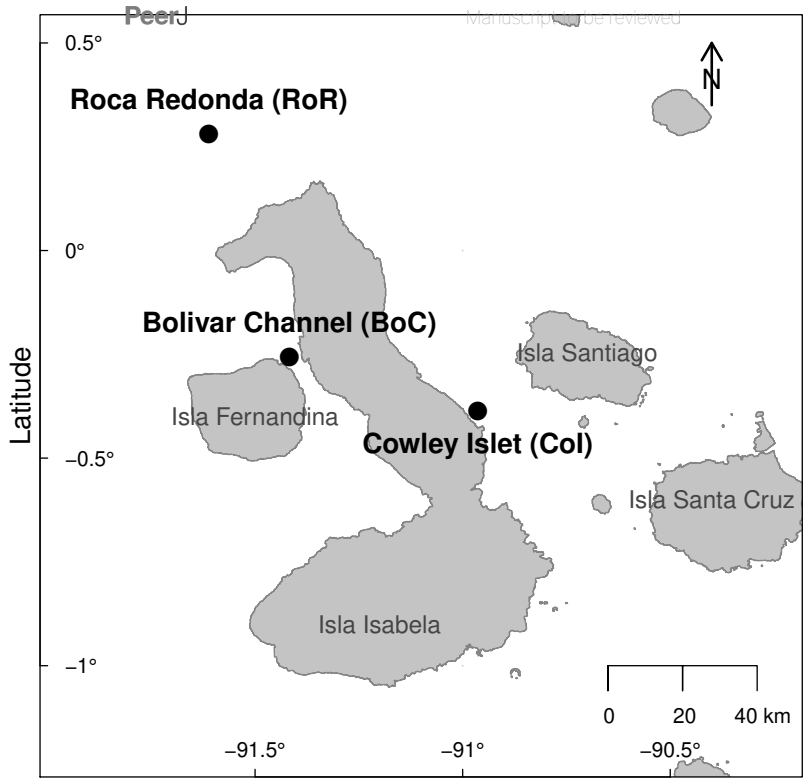




\section{Figure 2 (on next page)}

Principal component analysis (PCA) of observed water parameters at Cowley Islet (Col), Roca Redonda (RoR), and Bolivar Channel (BoC)

DO: dissolved oxygen, $\mathrm{Chl}$ a: chlorophyll a, $\mathrm{PO}_{4}^{3-:}$ phosphate, $\mathrm{NO}_{x}$ : nitrate/nitrite, $\mathrm{DOC}$ :

dissolved organic carbon, TEP: transparent exopolymers, POC: particulate organic carbon. 


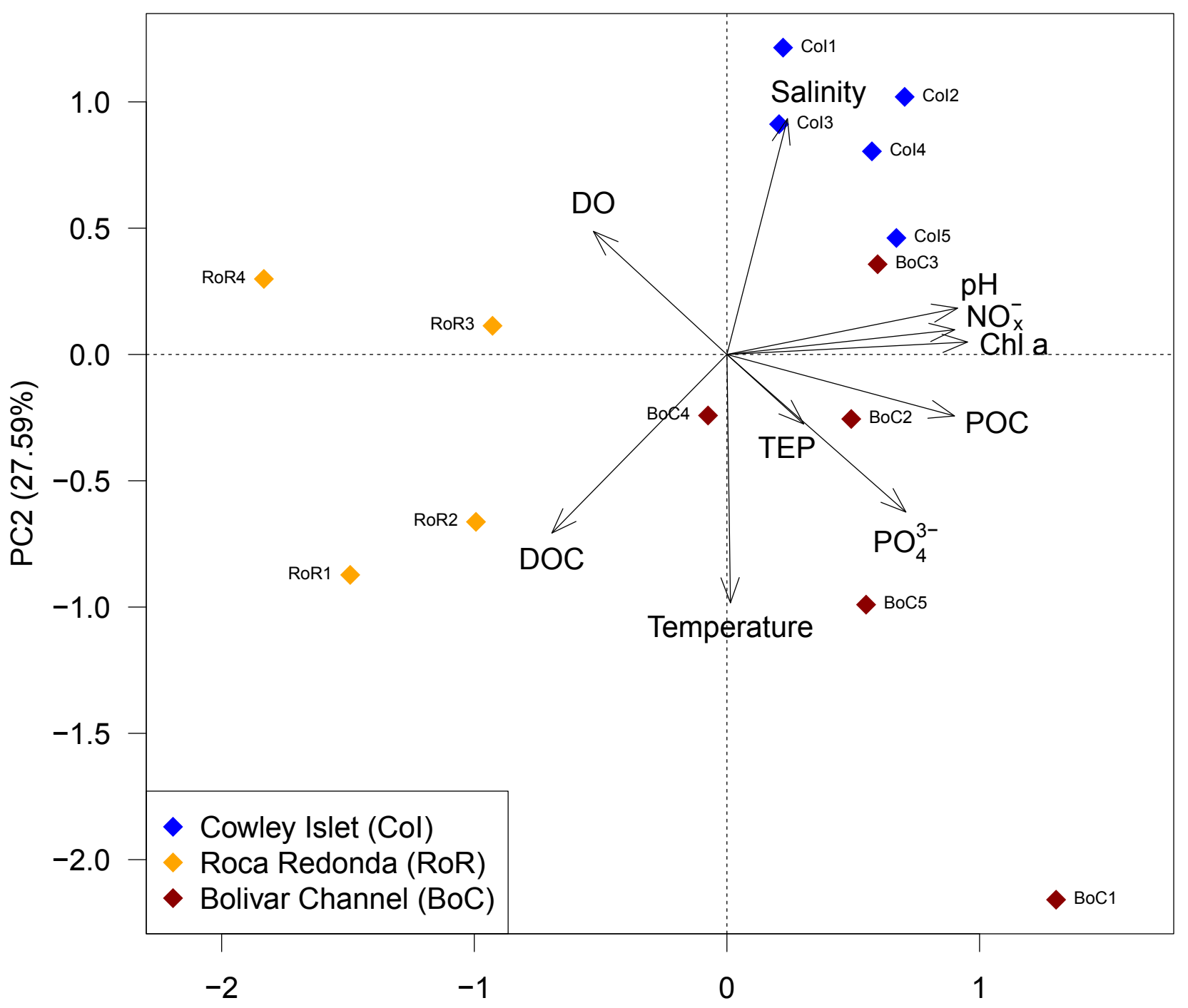

PC1 (41.89\%) 
Figure 3 (on next page)

Aggregation potential at Cowley Islet (Col), Roca Redonda (RoR), and Bolivar Channel (BoC) based on rolling tank experiment

The mean of total aggregate volume per rolling tank $+/$ - standard error is shown for each day during the experiment. Sample sizes: 5 (Col), 4 (RoR), 5 (BoC). 


\section{PeerJ}

Manuscript to be reviewed

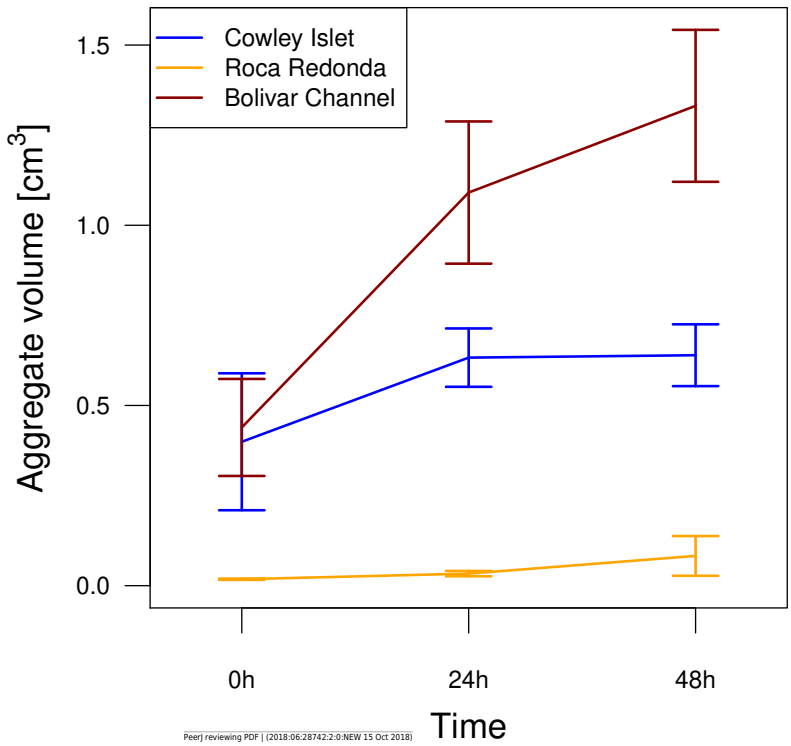


Figure 4 (on next page)

Composition of the free-living and particle-attached bacterial communities in the water column

A: Cluster diagram based on complete linkage hierarchical clustering of Bray-Curtis dissimilarity coefficients. Sample names specify replicate number at each of the three sampling sites: Cowley Islet (Col1-5), Roca Redonda (RoR1-4), and Bolivar Channel (BoC1-5), and size fraction: free-living $(>0.2 \mu \mathrm{m})$, particle-attached $(>3.0 \mu \mathrm{m})$. B: Taxonomic composition of the bacterial communities at class level. 


\section{(B)}
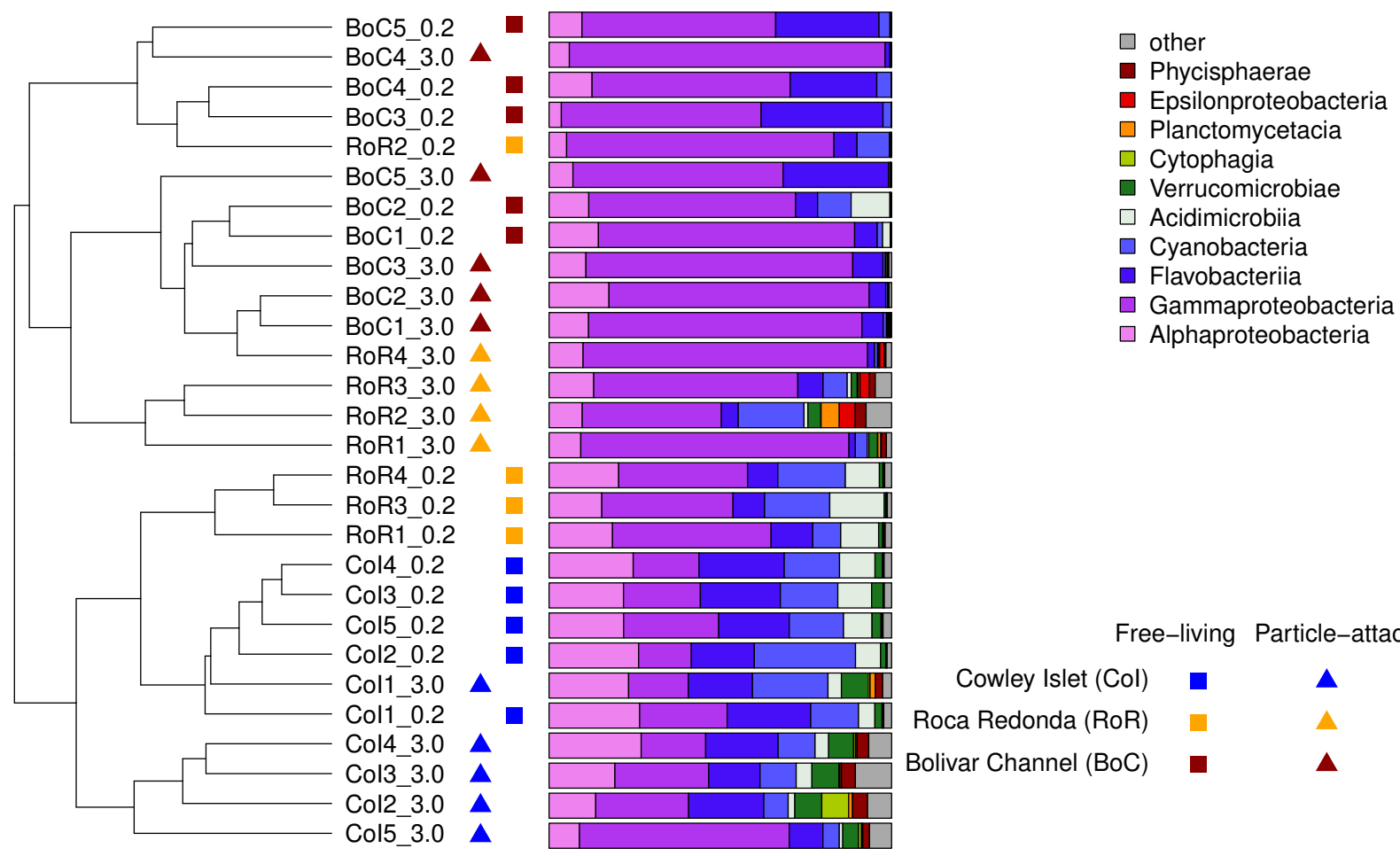

$\begin{array}{llllll}1.0 & 0.8 & 0.6 & 0.4 & 0.2 & 0.0\end{array}$

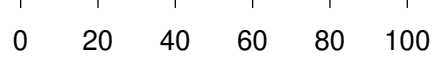

Bray-Curtis dissimilarity

Sequence proportion [\%]

Free-living Particle-attached

Cowley Islet (Col)

Roca Redonda (RoR)

Bolivar Channel (BoC)
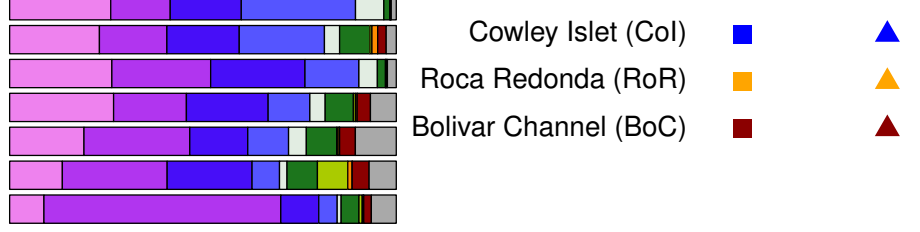
Figure 5 (on next page)

Dotplot of differentially abundant OTUs among sampling sites

A: Free-living bacterial communities. B: particle-attached bacterial communities. Sample names specify replicate number at each of the three sampling sites: Cowley Islet (Col1-5), Roca Redonda (RoR1-4), and Bolivar Channel (BoC1-5). The size of each dot represents centered log ratio (clr)-transformed sequences counts. Values higher than zero indicate enrichment compared to the other OTUs per sample. The taxonomic affiliation of each OTUs is provided on class (left side) and genus level (right side). Asterisks indicate OTUs detected as differentially abundant in both size fractions. 


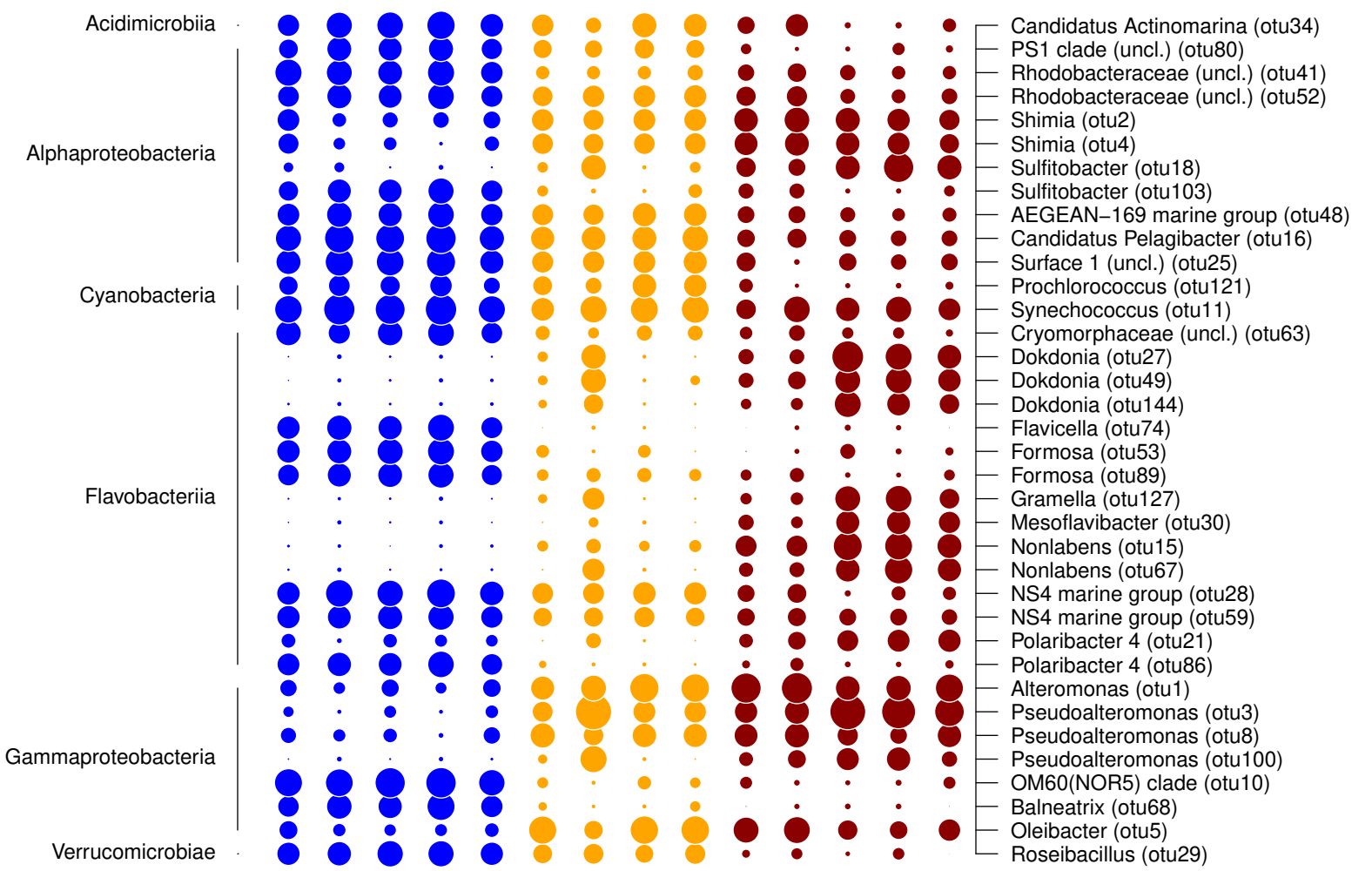

*

*

*

䊩

(B)

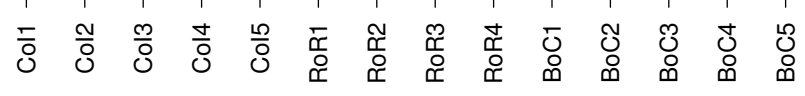

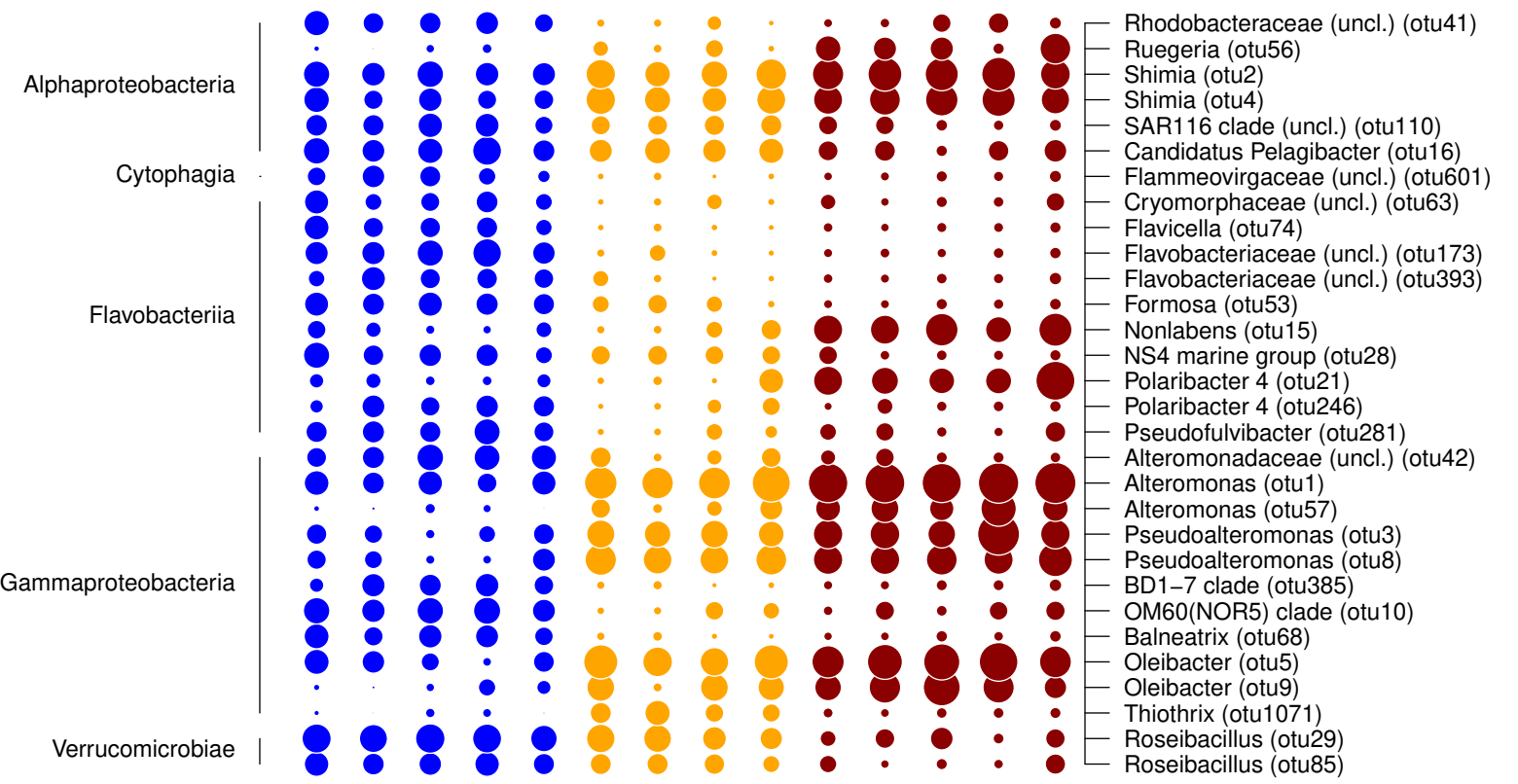

*

粪

*

米

奧

*

米

䊩

*

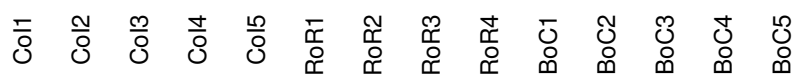




\section{Table $\mathbf{1}$ (on next page)}

Summary of observed water parameters and alpha diversity of free-living and particleattached bacterial communities in the water column 
1 Table 1: Summary of observed water parameters and alpha diversity of free-living and 2 particle-attached bacterial communities in the water column.

\begin{tabular}{|c|c|c|c|c|c|c|}
\hline Parameter $^{1}$ & $\begin{array}{c}\mathrm{T} \\
{\left[{ }^{\circ} \mathrm{C}\right]}\end{array}$ & $\mathrm{pH}$ & $\begin{array}{c}\text { Salinity } \\
\text { [psu] }\end{array}$ & $\begin{array}{c}\mathrm{DO} \\
{\left[\mathrm{mg} \mathrm{L}^{-1}\right]}\end{array}$ & $\begin{array}{c}\mathrm{NO}_{\mathrm{x}}^{-} \\
{\left[\mu \mathrm{mol} \mathrm{L}{ }^{-1}\right]}\end{array}$ & $\begin{array}{c}\mathrm{PO}_{4}^{3-} \\
{\left[\mu \mathrm{mol} \mathrm{L}^{-1}\right]}\end{array}$ \\
\hline \multicolumn{7}{|c|}{ Cowley Islet (CoI) } \\
\hline Min & 21.35 & 8.14 & 34.67 & 6.65 & 4.65 & 0.55 \\
\hline Median & 21.96 & 8.16 & 34.69 & 6.78 & 5.19 & 0.59 \\
\hline Max & 22.13 & 8.25 & 34.72 & 6.83 & 5.80 & 0.68 \\
\hline Group $^{2}$ & $\mathrm{a}$ & $\mathrm{a}$ & $\mathrm{a}$ & $\mathrm{a}$ & $\mathrm{a}$ & $\mathrm{a}$ \\
\hline \multicolumn{7}{|c|}{ Roca Redonda (RoR) } \\
\hline Min & 22.14 & 6.83 & 34.43 & 6.23 & 2.60 & 0.43 \\
\hline Median & 22.80 & 7.22 & 34.53 & 6.60 & 3.59 & 0.49 \\
\hline Max & 23.32 & 7.35 & 34.64 & 8.19 & 4.49 & 0.52 \\
\hline Group $^{2}$ & b & $\mathrm{b}$ & $\mathrm{b}$ & $a, b$ & $\mathrm{~b}$ & $b$ \\
\hline \multicolumn{7}{|c|}{ Bolivar Channel (BoC) } \\
\hline Min & 22.39 & 8.25 & 34.38 & 6.09 & 4.76 & 0.60 \\
\hline Median & 23.24 & 8.32 & 34.62 & 6.43 & 5.12 & 0.64 \\
\hline Max & 23.80 & 8.35 & 34.67 & 6.46 & 5.92 & 1.26 \\
\hline Group $^{2}$ & b & $\mathrm{c}$ & b & $\mathrm{b}$ & $\mathrm{a}$ & $\mathrm{a}$ \\
\hline Parameter $^{1}$ & $\begin{array}{c}\text { Chl a } \\
{\left[\mu \mathrm{g} \mathrm{L}^{-1}\right]}\end{array}$ & $\begin{array}{c}\mathrm{DOC} \\
{[\mu \mathrm{mol} \mathrm{L}-1]}\end{array}$ & $\begin{array}{c}\text { TEP } \\
{\left[\mu g X_{\mathrm{eq}} \mathrm{L}^{-1}\right]}\end{array}$ & $\begin{array}{c}\text { POC } \\
{\left[\mathrm{mg} \mathrm{L}^{-1}\right]}\end{array}$ & $\begin{array}{l}\text { InvS } \\
(\mathrm{FL})\end{array}$ & $\begin{array}{l}\text { InvS } \\
(\mathrm{PA})\end{array}$ \\
\hline \multicolumn{7}{|c|}{ Cowley Islet (CoI) } \\
\hline Min & 0.23 & 75.65 & 184.23 & 23.45 & 19.55 & 28.66 \\
\hline Median & 0.35 & 80.87 & 235.40 & 32.93 & 33.82 & 48.12 \\
\hline Max & 0.38 & 88.57 & 346.76 & 37.03 & 40.50 & 65.62 \\
\hline Group $^{2}$ & $\mathrm{a}$ & $\mathrm{a}$ & ns & $\mathrm{a}$ & $\mathrm{a}$ & $\mathrm{a}$ \\
\hline \multicolumn{7}{|c|}{ Roca Redonda (RoR) } \\
\hline Min & 0.09 & 88.96 & 142.57 & 18.46 & 2.31 & 4.41 \\
\hline Median & 0.13 & 100.54 & 293.20 & 20.64 & 21.04 & 17.80 \\
\hline Max & 0.19 & 112.73 & 323.67 & 22.37 & 24.99 & 20.29 \\
\hline Group $^{2}$ & $\mathrm{~b}$ & $\mathrm{~b}$ & ns & $\mathrm{b}$ & $a, b$ & $\mathrm{~b}$ \\
\hline \multicolumn{7}{|c|}{ Bolivar Channel (BoC) } \\
\hline Min & 0.15 & 86.76 & 243.33 & 25.38 & 4.19 & 3.16 \\
\hline Median & 0.33 & 92.14 & 303.36 & 36.65 & 8.46 & 4.85 \\
\hline Max & 0.40 & 97.99 & 459.05 & 44.09 & 14.75 & 7.67 \\
\hline Group $^{2}$ & $\mathrm{a}$ & $\mathrm{b}$ & ns & $\mathrm{a}$ & $\mathrm{b}$ & b \\
\hline
\end{tabular}

$3{ }^{1} \mathrm{~T}$ : temperature, DO: dissolved oxygen, $\mathrm{NO}_{\mathrm{x}}{ }^{-*}$ nitrate/nitrite, $\mathrm{PO}_{4}{ }^{3-}:$ phosphate, $\mathrm{Chl} \mathrm{a}$ :

4 chlorophyll a, DOC: dissolved organic carbon, TEP: transparent exopolymers, POC: particulate

5 organic carbon, InvS (FL): Inverse Simpson index of free-living bacterial communities, InvS

6 (PA): Inverse Simpson index of particle-attached bacterial communities. 
$7 \quad{ }^{2}$ Lower case letters indicate membership to significantly different groups based on pairwise

8 Wilcoxon posthoc tests between sampling sites (ns: no significant differences among sites based 9 on Kruskal Wallis tests). 


\section{Table 2 (on next page)}

Bray Curtis dissimilarity (BC) of bacterioplankton communities among sampling sites

Average within and between-group BC and analysis of similarity (ANOSIM) between sampling sites of free-living and particle-attached bacterial communities in the water column. 
1 Table 2: Bray Curtis dissimilarity (BC) of bacterioplankton communities among sampling

2 sites. Average within and between-group BC and analysis of similarity (ANOSIM) between 3 sampling sites of free-living and particle-attached bacterial communities in the water column.

\begin{tabular}{cccccc}
\hline & $\begin{array}{c}\text { Within-group } \\
\text { BC }\end{array}$ & Comparison & $\begin{array}{c}\text { Between-group } \\
\text { BC }\end{array}$ & ANOSIM R & P-value $^{1}$ \\
\hline Free-living & 0.67 & & & 0.63 & $\mathbf{0 . 0 0 1}$ \\
CoI & 0.26 & CoI - RoR & 0.61 & 0.72 & $\mathbf{0 . 0 1 7}$ \\
RoR & 0.55 & CoI - BoC & 0.89 & 0.89 & $\mathbf{0 . 0 1 7}$ \\
BoC & 0.64 & RoR - BoC & 0.71 & 0.29 & 0.108 \\
\hline Particle-attached & 0.70 & & & 0.83 & $\mathbf{0 . 0 0 1}$ \\
CoI & 0.50 & CoI - RoR & 0.75 & 0.96 & $\mathbf{0 . 0 1 5}$ \\
RoR & 0.55 & CoI - BoC & 0.91 & 1.00 & $\mathbf{0 . 0 1 5}$ \\
BoC & 0.49 & RoR - BoC & 0.61 & 0.48 & $\mathbf{0 . 0 1 9}$ \\
\hline
\end{tabular}

$4 \quad{ }^{1}$ For pairwise comparisons between the individual sampling sites, Cowley Islet (CoI), Roca

5 Redonda (RoR), and Bolivar Channel (BoC), false discovery rate (FDR)-adjusted p-values are

6 shown. P-values defined as significant at a threshold of 0.05 are highlighted in bold. 


\section{Table 3(on next page)}

Contribution of sampling site or temperature and $\mathrm{pH}$ to explaining variation in the composition of free-living and particle-attached bacterioplankton communities based on redundancy analysis (RDA)

Variation partitioning was used to test pure effects accounting for the variation explained by the other factors in the model. Akaike Information Criterion (AIC) and adjusted R squared are provided as goodness-of-fit metrics. 
1 Table 3: Contribution of sampling site or temperature and $\mathbf{p H}$ to explaining variation in the 2 composition of free-living and particle-attached bacterioplankton communities based on 3 redundancy analysis (RDA). Variation partitioning was used to test pure effects accounting for 4 the variation explained by the other factors in the model. Akaike Information Criterion (AIC) and 5 adjusted $\mathrm{R}$ squared are provided as goodness-of-fit metrics.

\begin{tabular}{|c|c|c|c|c|c|}
\hline Explanatory variable & AIC & Adjusted R squared & $\mathrm{F}$ & $\mathrm{df}^{1}$ & P-value ${ }^{2}$ \\
\hline \multicolumn{6}{|l|}{ Free-living } \\
\hline Sampling site & 85.31 & 0.571 & 9.65 & 2,11 & 0.001 \\
\hline Temperature $+\mathrm{pH}$ & 91.20 & 0.347 & 4.45 & 2,11 & 0.006 \\
\hline Temperature (pure) & & 0.348 & 7.40 & 1,11 & 0.004 \\
\hline $\mathrm{pH}$ (pure) & & 0.032 & 1.58 & 1,11 & 0.187 \\
\hline \multicolumn{6}{|l|}{ Particle-attached } \\
\hline Sampling site & 84.82 & 0.489 & 7.21 & 2,11 & 0.001 \\
\hline Temperature $+\mathrm{pH}$ & 89.37 & 0.292 & 3.69 & 2,11 & 0.003 \\
\hline Temperature (pure) & & 0.213 & 4.61 & 1,11 & 0.008 \\
\hline $\mathrm{pH}$ (pure) & & 0.100 & 2.70 & 1,11 & 0.015 \\
\hline
\end{tabular}

61 degrees of freedom (numerator, denominator).

$7 \quad 2$ P-values defined as significant at a threshold of 0.05 are highlighted in bold. 